\title{
Mapa józefińska Galicji (1779-1783) w przededniu edycji. Przedmiot i założenia programu wydawniczego
}

\author{
Waldemar Bukowski, Andrzej Janeczek
}

\section{Charakterystyka źródła}

Mapy topograficzne wielonarodowej monarchii habsburskiej oraz innych krajów rządzonych przez władców tej dynastii, wykonane w latach 1763-1787 w ramach tzw. zdjęcia józefińskiego (Josephinische Landesaufnahme), cieszą się we współczesnej literaturze zainteresowaniem oraz wysoką oceną jako dzieło pionierskie, kamień węgielny kartografii AustroWęgier przed 1918 r., praca monumentalna, którą można zaliczyć do najwybitniejszych kartograficznych osiągnięć schyłku XVIII w. ${ }^{1}$ Seria map józefińskich porównywana jest z przełomową w rozwoju kartografii mapą Francji Césara-François Cassiniego de Thury, której ustępuje swą zaczątkową triangulacją i niejednorodnością używanych metod pomiaru, lecz przewyższa ją zastosowaną, trzykrotnie większą, skalą odwzorowania oraz rozleglejszym zasięgiem.

Zyskujące tak pochlebną opinię mapy powstały w wyniku wielkiej akcji kartowania wszystkich krajów, znajdujących się pod władaniem domu habsburskiego. Projekt zdjęcia topograficznego całości terytoriów imperium Habsburgów zrodził się po doświadczeniach przegranej wojny siedmioletniej (1756-1763), gdy feldmarszałek Franz Moritz Lacy zaapelował o zaopatrzenie armii w szczegółowe mapy terenowe, ich brakiem tłumacząc niepowodzenia operacji na Śląsku. Spełniając postulaty dowódców wojskowych cesarzowa Maria Teresa zarządziła wykona-

\footnotetext{
${ }^{1}$ 0. Regele, Beiträge zur Geschichte der staatlichen Landesaufnahme und Kartographie in Österreich bis zum Jahre 1918, Wien 1955, s. 27; J. Dörflinger, Vom Aufstieg der Militärkartographie bis zum Wiener Kongress (1684-1815), w: I. Kretschmer, J. Dörflinger, F. Wawrik, Österreichische Kartographie. Von den Anfängen im 15. Jahrhundert bis zum 21. Jahrhundert, ,Wiener Schriften zur Geographie und Kartographie", 15 (2004), s. 78.

${ }_{2}^{2}$ Nieokrąła skala liczbowa mapy wynikła z używania antropometrycznych jednostek długości; cal wiedeński wynosił 0,02634 m,
}

nie dokładnego zdjęcia całej monarchii, co zlecono Kwatermistrzostwu Sztabu Generalnego. Postanowiono wykonać próbne zdjęcie topograficzne na zachowanych przy Austrii terenach Śląska: w latach 1763-1764 powstała mapa księstwa cieszyńskiego, opawskiego i nyskiego. Po tej, zakończonej sukcesem, próbie przystąpiono do kartowania poszczególnych krajów, zaczynając od zdjęcia Czech. Od 1765 r. zadanie nadzorował Józef II, dopuszczony do współrządów. Przyjęto jednolite zasady sporządzania map, $\mathrm{z}$ reguły w skali $1: 28800$ (1 cal na mapie odpowiadał 1000 kroków, czyli 400 sążniom wiedeńskim w terenie $)^{2}$, na podstawie pomiarów terenowych, przy zastosowaniu triangulacji, ale też metody à la vue („okomiaru”), z użyciem stolika, liniału przeziernikowego, busoli, astrolabium i kwadrantu. Do 1787 r. skartowano większość ziem monarchii na ponad 3500 sekcjach. Cały materiał, głęboko utajniony, został złożony w archiwum Nadwornej Rady Wojennej (Hofkriegsrat), poprzednika Archiwum Wojennego (Kriegsarchiv), w którym do dzisiaj jest przechowywany ${ }^{3}$. Zaangażowanie się państwa w prace kartograficzne i powierzenie tego zadania instytucji wojskowej przyniosło doskonałe efekty: sprawnie, w krótkim czasie, według nowoczesnych w tamtych warunkach metod, sporządzono wielkoskalowe mapy rozległego terytorium o powierzchni 570 tys. $\mathrm{km}^{2}$, obejmującego obszar Europy środkowej

krok (Schritt) równał się ok. 0,75 m, sążeń wiedeński (Wiener Klafter) to $1,8965 \mathrm{~m}$.

${ }^{3}$ Charakterystykę zbiorów kartograficznych Archiwum Wojennego dał E. Hillbrand, Die Kartensammlung des Kriegsarchivs Wien, „Mitteilungen des Österreichischen Staatsarchivs", 28 (1975), s. 183-196; tenże, Z problematyki badawczej źródłowych zasobów kartograficznych Kriegsarchiv w Wiedniu, „Sprawozdania z Posiedzeń Komisji Naukowych PAN, Oddział w Krakowie”, 30 (1986), 1-2, s. 234-236. 
oraz znaczne połacie Europy wschodniej, południowej i zachodniej (ryc. 1$)^{4}$.

Część zdjęcia józefińskiego stanowi - w odniesieniu do południowych ziem Rzeczypospoli- tej zajętych przez Austrię w pierwszym rozbiorze w 1772 r. - sporządzona w latach 1779-1783 mapa Królestwa Galicji i Lodomerii, w polskim piśmiennictwie zwana zwyczajowo mapą Miega,

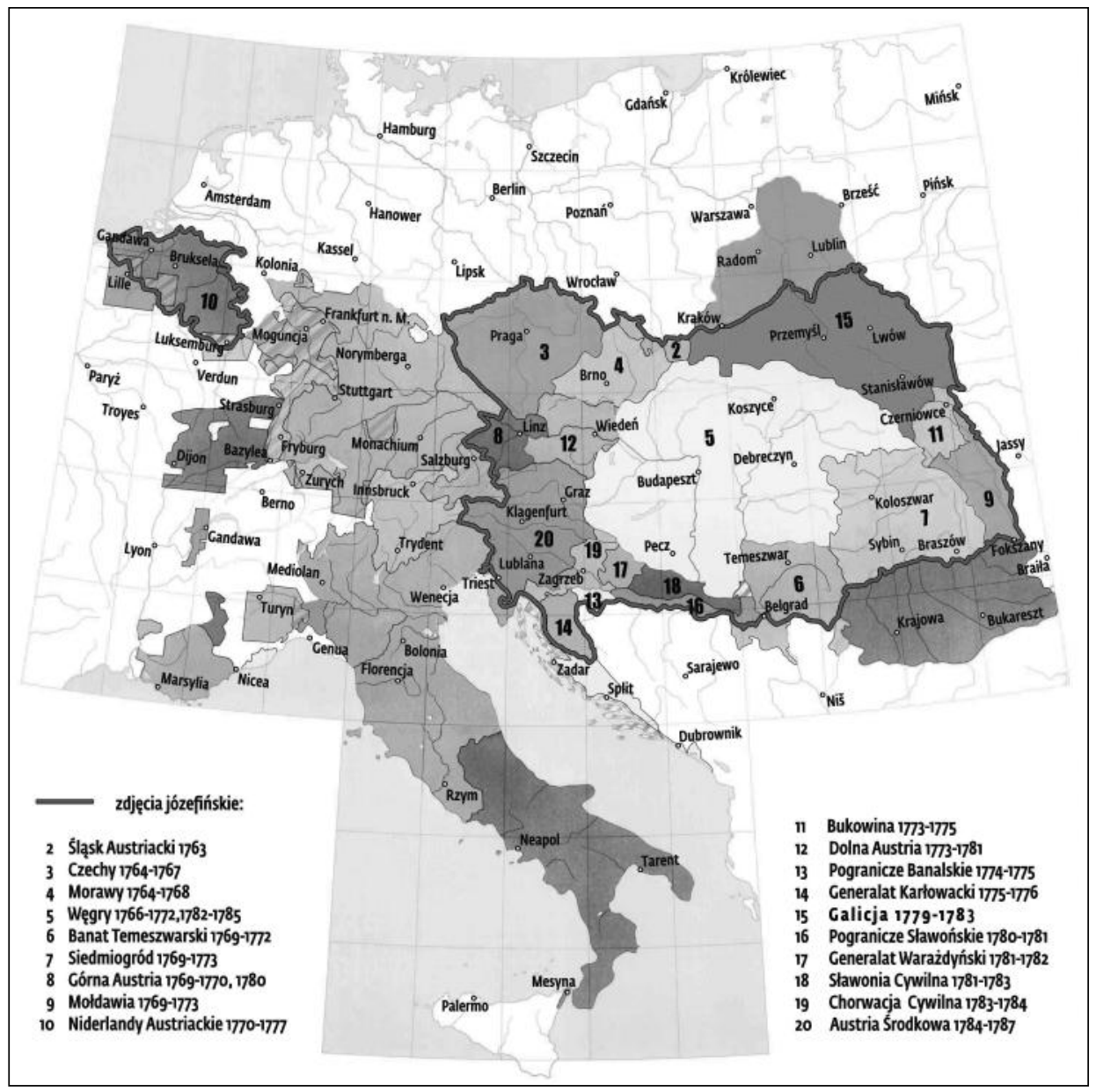

Ryc. 1. Zdjęcia topograficzne austriackiego Kwatermistrzostwa Sztabu Generalnego 1749-1854. Mapa ścienna, oprac. E. von Nischer-Falkenhof, ok. 1932-1933 r. (rękopiśmienny oryginał w Archiwum Wojennym w Wiedniu), na nowo oprac. J. Dörflinger przy pomocy M. Wateleta, w: J. Dörflinger, „Die Landesaufnahmen des österreichischen Generalquartiermeisterstabes” 1749-1854, „Karlsruher Geowissenschaftliche Schriften“, Reihe C, Bd. 2 (1989), mapa załącznikowa

\begin{abstract}
${ }^{4}$ Geneza wojskowego kartowania ziem monarchii habsburskiej, ogólne założenia tej akcji, jej przebieg i rezultaty są stosunkowo dobrze poznane dzięki badaniom historyków kartografii: J. Paldus, Die militärischen Aufnahmen im Bereiche der Habsburgischen Länder aus der Zeit Kaiser Josephs II., „Denkschriften. Akademie der Wissenschaften in Wien, Philosophisch-historische Klasse“, Bd. 63 (1919), Abh. 2; 0. Regele, Beiträge zur Geschichte; E. Hofstätter, Beiträge zur Geschichte der österreichischen Landesaufnahmen, T. 1-2, Wien 1989; J. Dörflinger, Die Landesaufnahmen des österreichischen Generalquartiermeisterstabes 1749-1854, „Fachhochschule Karlsruhe. Karlsruher Geowis-
\end{abstract}

senschaftliche Schriften". Reihe C: Alte Karten. Bd. 2 (1989); tenże, Die Österreichische Kartographie im 18. und zu Beginn des 19. Jahrhunderts unter besonderer Berücksichtigung der Privatkartographie zwischen 1780 und 1820, Bd. 1: Österreichische Karten des 18. Jahrhunderts, Wien 1994, s. 63-65; A. Konias, Kartografia topograficzna Śląska Cieszyńskiego i zaboru austriackiego od II połowy XVIII w. do początku XX w. Katowice 2000; R. Rill, Die Anfänge der Militärkartographie in den habsburgischen Erblanden: Die Josephinische Landesaufnahme von Böhmen und Mähren nach hofkriegsrätlichen Quellen, „Mitteilungen des Österreichischen Staatsarchivs", 49 (2001), s. 183-202. 
od nazwiska kierującego większością prac oficera Sztabu Generalnego, Friedricha von Miega.

Mapa jest przechowywana w Archiwum Wojennym w Wiedniu pod sygnaturą B IXa 390. W opisie archiwalnym nosi tytut: Karte des Königreiches Galizien und Lodomerien. Nie jest to jej tytuł oryginalny; ani całe zdjęcie doby józefińskiej, ani mapy poszczególnych krajów nie mają współczesnych sobie jednolitych określeń i bywały nazywane na różne sposoby, najczęściej po prostu mapą wojskową. We współczesnej terminologii określa się je jako zdjęcie józefińskie lub pierwsze zdjęcie wojskowe. Początkowo utajniona ze względu na znaczenie militarne, nigdy nie została opublikowana i pozostaje do dziś w rękopisie. Nawet jej mocno zredukowana kopia w skali (1:115 200), sporządzona na 24 arkuszach, klasyfikowana jako mapa operacyjna, nie została udostępniona do użytku cywilnego i pozostawała w jednym egzemplarzu $\mathrm{w}$ dyspozycji cesarza.

Mapa józefińska Galicji składa się z 413 znormalizowanych arkuszy oraz dodatkowych arkuszy o różnym formacie, dostosowanym do zasięgu terytoriów pogranicznych, wykraczających poza regularną siatkę podziału na sekcje. Jej łączna powierzchnia to ok. $115 \mathrm{~m}^{2}$. Oprócz oryginału pod tą samą sygnaturą przechowywane są dwa komplety rękopiśmiennych kopii. Mapie towarzyszy sześć obszernych foliałów zawierających opisy kartowanego terenu, a także dwa tomy alfabetycznego spisu miejscowości Galicji i sprostowań ich pisowni ${ }^{5}$ oraz tom kalkulacji trygonometrycznych.

Wysoka ocena, przyznawana w literaturze całości dzieła opatrywanego mianem zdjęcia józefińskiego, należy się w równym stopniu jego galicyjskiej części. Materiał kartograficzny i opisowy na zdjęciu józefińskim Galicji imponuje swym bogactwem i obfitością. To niezrównane na tle ówczesnego stanu opracowania kartograficznego ziem Rzeczypospolitej osiągnięcie, zarówno ze względu na zastosowane metody wstępnej triangulacji i pomiarów $\mathrm{w}$ terenie, wielką skalę, rozległość kartowanego terenu, jak i ze względu na ogromny zasób przekazanych treści oraz stosunkowo dużą precyzję. Mapa rejestruje stan tych ziem na progu epoki roz- biorowej, już pod rządami obcego mocarstwa, lecz jeszcze przed głębokimi przemianami gospodarczymi i społecznymi, które przekształciły krajobraz staropolski i zatarly jego cechy. Takich map doba staropolska po sobie nie pozostawiła, jeśli nie liczyć pojedynczych map majątkowych i planów miast czy twierdz. $Z$ wymienionych powodów mapa Galicji jest więc szczególnie przydatna do badań historycznych oraz do studiów prowadzonych w ramach innych dyscyplin, zajmujących się na przykład przemianami dawnego krajobrazu przyrodniczego. Jednak dopiero teraz dochodzi do skutku zamysł udostępnienia jej drukiem.

\section{Wiedza o mapie i jej dotychczasowe wykorzystanie}

Mapa józefińska Galicji, o której informacje były utajnione (istnienie opisów ujawniono dopiero w 1864 r.), przez długi czas znana była jedynie wąskiemu kręgowi osób upoważnionych przez cesarza. Pierwsza publiczna prezentacja, przerywająca definitywnie okres braku do niej dostępu, miała miejsce na wystawie światowej w Wiedniu w 1873 r. Mape pokazano na dodatkowej ekspozycji poświęconej historii przemysłu i wynalazków, pośród innych dzieł kartograficznych po części wypożyczonych z Archiwum Wojennego, pod nazwą Aufnahme von Galizien, unter Oberstlieutenant Mieg, $1781^{6}$. Krótką informację o niej podał generał Johann Roskiewicz (1831-1902), w przygotowanym na tę okazję zarysie dziejów kartografii austriackiej. Wczesnym, przypadającym na przełom wieków XIX i XX przykładem wykorzystania mapy w badaniach naukowych, a zarazem w procesie sądowym są prace lwowskich historyków, Aleksandra Czołowskiego (18651944) oraz Oswalda Balzera (1858-1933), przygotowane w związku ze sporem granicz-

\footnotetext{
${ }^{5}$ Berichtigungen in der Schreibweise der in der Militär-Aufnahme von Galizien und Lodomerien vorkommenden Ortschaften, t. 1-2, 1790; Kartensammlung, K VII h 22 Epsilon.

${ }^{6} \mathrm{~J}$. Roskiewicz, Kartographie, w: Weltausstellung 1873 in Wien. Beiträge zur Geschichte der Gewerbe und Erfindungen Oesterreichs von der Mitte des XVIII. Jahrhunderts bis zur Gegenwart, hrsg. von der General-direction, redigirt von Prof. Dr. W.F. Exner, 2. Reihe, Wien 1873, s. 253 (tenże, Die Kartographie in Österreich vom Jahre 1750 bis zum Jahre 1873, II. vermehrte Auflage, Wien 1875).
} 
nym o Morskie Oko, który rozgorzał mocniej od 1890 r. między Galicją i Węgrami. Obaj badacze analizowali przekaz zawarty na arkuszu 30. mapy, zarówno oryginału jak kopii, pośród innych źródeł kartograficznych i pisanych, uwzględnionych $\mathrm{w}$ argumentacji przedstawionej trybunałowi rozjemczemu w Grazu, jak też podanej opinii publicznej, głęboko poruszonej sprawą zatargu?.

Pierwsze opracowanie monograficzne mapa uzyskała dzięki studiom Josefa Paldusa (18631937), pułkownika armii austro-węgierskiej, kierującego Oddziałem Kartografii Archiwum Wojennego w latach I wojny światowej, później zaś czechosłowackiego delegata przy tym Archiwum. Najpierw, w 1916 r., przedstawił on charakterystykę prac kartograficznych podjętych po zajęciu Galicji, w tym map demarkacji nowych granic, "politycznego” zdjęcia przygotowanego przez Josepha Liesganiga oraz mapy józefińskiej. W 1919 r. ukazała się jego treściwa, do dziś zachowująca wartość, praca poświęcona całemu zespołowi map józefińskich, omawiająca organizację prac, stosowane metody, przebieg pomiarów terenowych i ich efekty ${ }^{8}$. Jednocześnie w latach 1919-1920 pracował $\mathrm{w}$ archiwach wiedeńskich Ludomir Sawicki (1884-1928), profesor geografii Uniwersytetu Jagiellońskiego. Prowadził on rozległe kwerendy z ramienia Polskiej Komisji Likwidacyjnej, która na mocy traktatu w St. Germain miała określić polskie roszczenia do dóbr kulturalnych i naukowych po byłej monarchii austro-węgierskiej. L. Sawicki sporządził wówczas spis map dotyczących ziem polskich i wiadomość o tej mapie zamieścił w opublikowanym w 1920 r. katalogu9. Sam zaś zają się bliżej inną, równie cenną przechowywaną tam

\footnotetext{
${ }^{7}$ A. Czołowski, Sprawa sporu granicznego przy Morskim Oku. Wywód historyczno-prawny, Lwów 1894, s. 52; 0. Balzer, 0 Morskie Oko. Wywód praw polskich przed sądem polubownym w Gradcu, Lwów 1906, s. 164; (wcześniejsza publikacja w „Przewodniku Naukowo-Literackim", 22-23 (1904-1905).

${ }^{8}$ J. Paldus, Die Einverleibung Galiziens und der Bukowina in die österreichische Monarchie im Jahre 1772 , „Mitteilungen der k. k. geographischen Gesellschaft in Wien", 59 (1916), s. 417-455; tenże, Die militärischen Aufnahmen, o mapie Galicji zwłaszcza na s. 46-58.

${ }^{9}$ L. Sawicki, Spis map Archiwum Wojennego w Wiedniu odnoszących się do ziem polskich, Warszawa 1920, nr 1074.
}

mapą, już spoza serii józefińskiej, ale należącą do jej pokłosia, to jest mapą tzw. Galicji Zachodniej (Nowej), obejmującą ziemie trzeciego zaboru austriackiego Rzeczypospolitej, której wkrótce poświęcił szczegółową monografię w języku niemieckim ${ }^{10}$. Mapa józefińska Galicji nie została objęta rewindykacją, natomiast, już wówczas, zdając sobie dobrze sprawę z jej wartości dla nauki polskiej, sprowadzono czarno-białe reprodukcje samych map na szklanych negatywach do Biblioteki Narodowej w Warszawie. Fotograficzne odbitki części mapy trafiły też, dzięki K. Buczkowi (19021983), do krakowskiej Komisji Atlasu Historycznego Polski PAU. Kolejno wykonywane, niekompletne kopie pozyskały również inne instytucje naukowe w kraju. Przez długie lata służyły one polskim badaczom. Jakość starych, czarno-białych zdjęć i mikrofilmów, utrzymujących się ledwo na granicy czytelności, nie pozwalała jednak na wydobycie wielu informacyjnych walorów mapy. Znano zaledwie jakby nikły cień autentyku, a zupełnie poza obiegiem pozostawały opisy. Potrzeba publikacji całości źródła była jednak coraz szerzej uświadamiana w środowisku historyków.

\section{Narodowe edycje map józefińskich}

Polski projekt edycji mapy mieści się w rzędzie innych narodowych edycji map józefińskich. Ze względu na znaczenie zdjęcia józefińskiego jako pomnika kartografii europejskiej i wartościowego materiału źródłowego, w wielu krajach wysuwano postulaty publikacji zabytku w postaci faksymile map i krytycznej edycji części opisowej. W latach sześćdziesiątych XX w. rozpoczęto wielotomową edycję mapy austriackich $\mathrm{Ni}$ derlandów ${ }^{11}$. Od lat dziewięćdziesiątych XX w.

\footnotetext{
${ }^{10}$ L. Sawicki, Obristen Anton Freiherr Mayer von Heldensfeld topographische Aufname Westgaliziens in den Jahren 1801-1804, „Prace Instytutu Geograficznego Uniwersytetu Jagiellońskiego", z. 10 (1928).

${ }^{1}$ Carte de Cabinet de Pays-Bas autrichiens levée à l'initiative du comte de Ferraris. Mémoires historiques, chronologiques et oeconomiques, 12 tomów map, 12 tomów opisów, Bruxelles 1965-1974. Nowa edycja, zob. De grote atlas van Ferraris: de eerste atlas van België : Kabinetskaart van de Oostenrijkse Nederlanden en het Prinsbisdom Luik, 1777. Le grand atlas de Ferraris: le premier atlas de la Belgique: carte de Cabinet des Pays-Bas autrichiens et de la Principauté de Liège, 1777, wyd W. Bracke, S. Lammens, Brussel 2009, 2011.
} 
ruszyły, pod egidą agend rządowych i narodowych akademii nauk, wielkie inicjatywy edytorskie w krajach byłej monarchii austrowęgierskiej objętych kartowaniem: w Słowenii i Chorwacji, a oprócz tego na Węgrzech i we Włoszech. Obecnie zakończona została faksymilowa edycja zdjęcia józefińskiego dla Słowenii ${ }^{12}$, zaawansowany jest projekt chorwacki ${ }^{13}$, trwają prace nad wydaniem mapy Karyntii. Wydano również mapę księstwa Wenecji, już spoza serii józefińskiej, sporządzoną w latach 1801-1805, lecz wykazującą wiele wspólnych $\mathrm{z}$ nią $\operatorname{cech}^{14}$.

W inny sposób, cyfrowy, zrealizowano węgierską publikację zdjęcia józefińskiego wraz z opisami dla Królestwa Węgier oraz Siedmiogrodu i Banatu ${ }^{15}$; obie edycje dostępne są na płytach DVD. Jeszcze inaczej postąpiono w Czechach: józefińskie zdjęcie Czech, Moraw i części Śląska zamieszczono w Internecie w serwisie Uniwersytetu Jana Evangelisty Purkyněgo, wraz z innymi materiałami kartograficznymi (mapą Muellera z 1720 r., zdjęciem franciszkowskim z lat 1836-1852, franciszko-józefińskim z lat 1876-1880 oraz mapami katastru z pierwszej połowy XIX w. $)^{16}$. Podobnie udostępniono $\mathrm{w}$ sieci zdjęcie józefińskie Styrii, w ramach pełnego serwisu kartograficznego kraju przygotowanego w systemie GIS (Digitaler Atlas Steiermark) ${ }^{17}$, a także w Belgii, w przypadku Carte de Cabinet des Pays-Bas autrichien ${ }^{18}$. Natomiast na Słowacji i na Ukrainie opublikowano jedynie drobne fragmenty mapy (w pracy ukraińskiej w jakości ustępującej oryginałowi i pozbawione koloru $)^{19}$. Mapa obecnego terytorium Słowacji została jednakże udostępniona w cyfrowej edycji węgierskiej.

\footnotetext{
${ }^{12}$ Slovenija na vojaškem zemljevidu 1763-1787, wyd. V. Rajšp i in., zvezek 1-7, Ljubljana 1995-2001.

${ }^{13}$ Hrvatska na tajnim zemljovidima XVIII. iXIX. stoljeća, wyd. M. Valentić i in., svazek 1-12, Zagreb 1999-2009.

${ }_{14}$ II Ducato di Venezia nella carta di Anton von Zach, wyd. M. Rossi, vol. 1-3, Treviso 2005; opracowanie monograficzne: M. Rossi, L'officina della Kriegskarte. Anton von Zach e le cartografie degli stati veneti, 1796-1805, Treviso 2007.

${ }^{15}$ Az első katonai felmérés: Magyar Királyság. Die Josephinische Aufnahme: Die erste militärische Vermessung. Königtum Ungarn, Buda-
}

\section{Organizacja prac edytorskich}

Rozmiary edycji mapy józefińskiej Galicji, podwójny - kartograficzny i tekstowy charakter zawartego w niej materiału źródłowego, jego nasycenie treścią wymagającą zaopatrzenia w rozwinięty aparat krytyczny i pomocniczy, ułatwiający użytkownikowi korzystanie z tego bogatego zasobu, przesądziły w sposób oczywisty o konieczności obrania zespołowego trybu pracy oraz zaangażowania kilku ekip edytorskich. Z tych względów materiał źródłowy został rozdzielony na cztery proporcjonalne części, z których każda jest przedmiotem opracowania powierzonego osobnemu zespołowi roboczemu. Przyjęto przy tym zasadę, że dla zachowania jednolitości edycji wszystkie prace muszą być ściśle skoordynowane i prowadzone w stałym porozumieniu między zespołami. Odpowiednio do liczby grup edytorskich opracowano cztery bliźniacze projekty badawcze o wspólnych założeniach i celach. Przedmiotem każdego z nich było skompletowanie podstawy wydania (opisów i map) wraz z tłumaczeniami, z zakresu przydzielonych sekcji, przygotowanie jej do dalszych zaawansowanych etapów prac edytorskich, a także opracowanie opatrzonej pełnym aparatem i zamkniętej do druku edycji jednego tomu, wybranego $\mathrm{z}$ tego zakresu. Dwa pierwsze projekty, którym przypadła rola „przecierania szlaku”, jeden pod kierunkiem W. Bukowskiego z Instytutu Historii PAN, a drugi Z. Nogi z Uniwersytetu Pedagogicznego w Krakowie, objęły sekcje 1-201 i zostały już wykonane w latach 2008-2010, w ramach dwóch grantów Ministerstwa Nauki i Szkolnictwa Wyższego. Projekt trzeci, którym kieruje A. Janeczek z Instytutu Archeologii i Etnologii PAN w Warszawie, obejmuje sekcje 202-312 i został w części zrealizowany dzięki grantom

pest 2004, 2006; Az első katonai felmérés: Erdély és a Temesi Bánság. Die erste militärische Vermessung. Siebenbürgen und das Banat des Temes, Budapest 2005, 2007.

${ }^{16}$ Dostęp: http://oldmaps.geolab.cz, 8 marca 2013.

${ }^{17}$ Dostęp: http://www.gis.steiermark.at, 8 marca 2013.

${ }^{18}$ Dostęp: http://belgica.kbr.be/fr/coll/cp/cpFerraris fr.html, 8 marca 2013.

${ }^{19}$ B. Klein, Významné mestá Slovenska na tajných mapách 18. storočia, Bratislava 2003; H. P. Petryšyn, Karta F. fon Miga (1779-1782 r.) jak džerelo do mistoznavstva Halyčyny, L'viv 2006. 


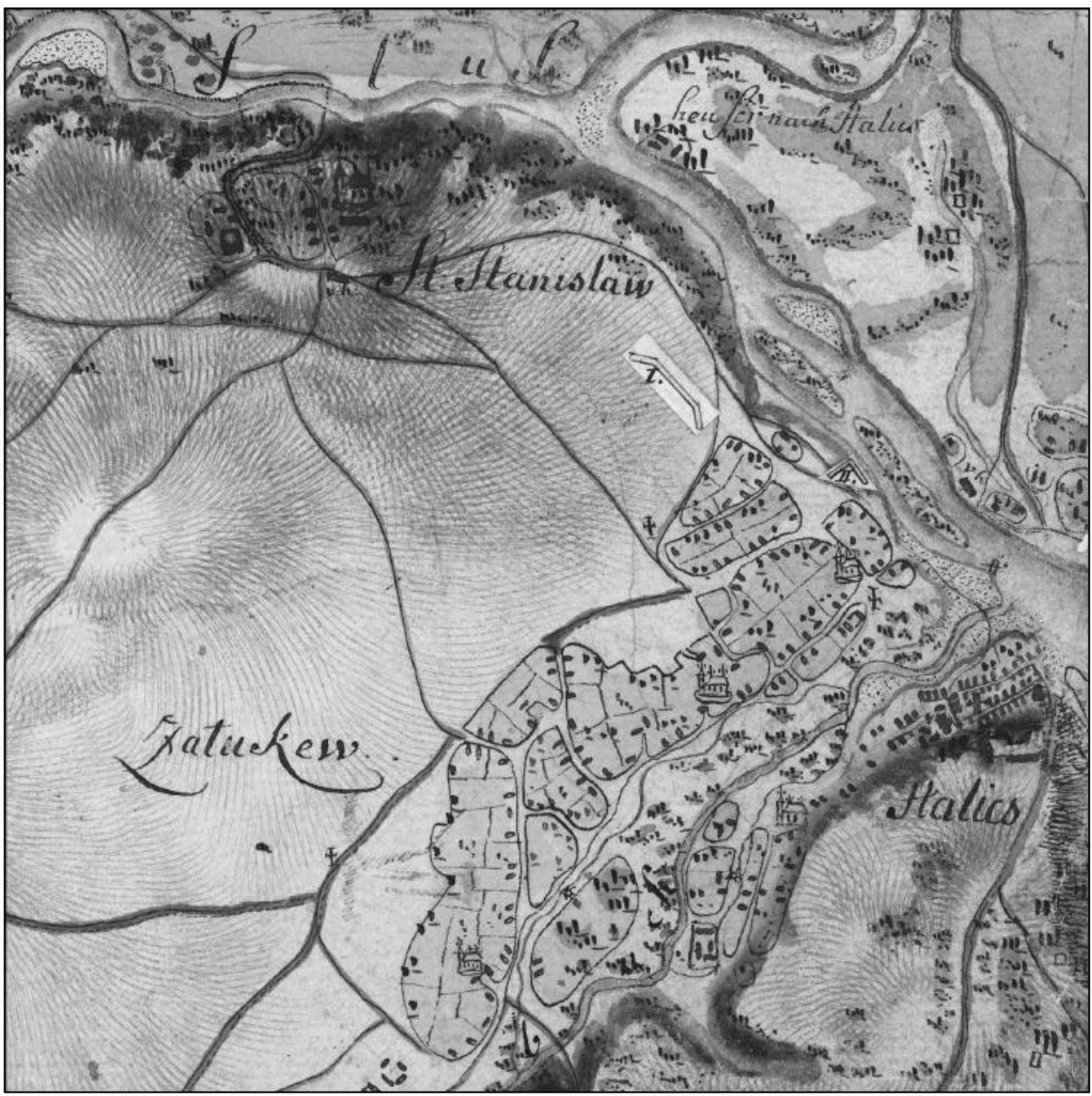

Ryc. 2. Przykładowy fragment oryginału mapy, kolumna XXII, arkusz 300. Halicz z najblizszą okolicą (Kriegsarchiv, B IXa 390)

Fundacji na rzecz Nauki Polskiej (lata 20092011) oraz Ministerstwa Nauki i Szkolnictwa Wyższego (lata 2011-2014). Projekt czwarty, kierowany przez Z. Budzyńskiego z Uniwersytetu Rzeszowskiego, obejmuje ostatnią serię sekcji z zakresu 313-413 i prowadzony jest w ramach grantu przyznanego przez Narodowe Centrum Nauki (lata 2012-2015). Wszystkie prace są realizowane przy wsparciu organizacyjnym i merytorycznym Stacji

\footnotetext{
${ }^{20}$ Wcześniejsze informacje 0 początkowej fazie projektu, zob. W. Bukowski, Die handschriftliche topographische Karte des Konigreiches Galizien und Lodomerien - die sogenannte Miegkarte - der Jahre 1775-1783 in den Sammlungen des Kriegsarchivs in Wien sowie das Projekt ihrer Herausgabe, ,Jahrbuch des Wissenschaftlichen Zentrums
}

Naukowej PAN w Wiedniu i jej dyrektora B. Dybasia. W przygotowaniu partii tekstowych całego zasobu bierze udział także $€$. Walczy z Krakowa, zaś wspólnym konsultantem zagadnień kartograficznych jest J. Ostrowski z Warszawy ${ }^{20}$.

To jedno spójne zamierzenie wydawnicze przechodzi obecnie płynnie w następną fazę, za sprawą grantu udzielonego przez Ministerstwo Nauki i Szkolnictwa Wyższego ze środ-

der Polnischen Akademie der Wissenschaften in Wien", 1 (2007-2008), s. 145-156; także W. Bukowski, B. Dybaś, A. Janeczek, Z. Noga, Edycja rękopiśmiennej mapy topograficznej Galicji z lat 1775-1783 (tzw. mapy Miega) z Archiwum Wojennego w Wiedniu, „Kwartalnik Historii Kultury Materialnej”, 59 (2011), nr 1, s. 101-105. 


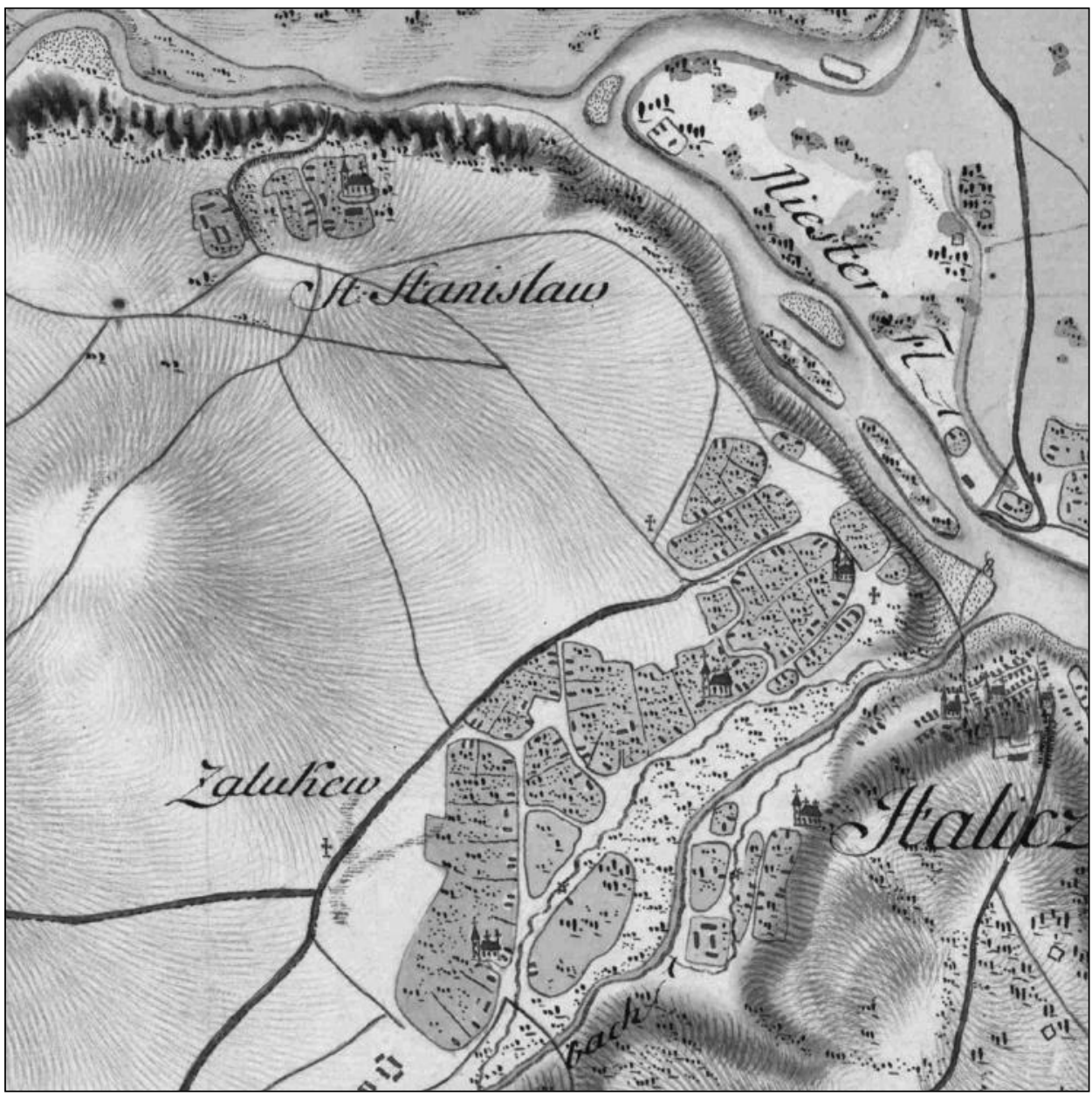

Ryc. 3. Przykładowy fragment pierwszej kopii mapy, kolumna XXII, arkusz 300. Halicz z najbliższą okolicą (Kriegsarchiv, B IXa 390)

ków Narodowego Programu Rozwoju Humanistyki ${ }^{21}$. Dzięki temu sfinansowany będzie stopniowo, w ciągu pięciu lat, druk siedmiu tomów. Zgodnie $\mathrm{z}$ planem cała mapa winna być opublikowana $\mathrm{w}$ ciągu czternastu lat, o ile zostanie zapewnione jej dalsze subsydiowanie.

\section{Podstawa wydania \\ Mapy}

Zdjęcie wojskowe Galicji w skali 1:28 800 składa się z 413 barwnych sekcji, ułożonych w 29 południkowych kolumnach. Każda sekcja powinna mierzyć $24 \times 16$ cali, czyli $63,2 \times$ $42,1 \mathrm{~cm}$, jednakże dają się zauważyć odstępstwa od tej normy, nawet rzędu kilku procent.
Poza arkuszami o standardowym formacie mapa zawiera arkusze o różnych, wykraczających poza moduł wymiarach, dostosowanych do kształtu terytorium Galicji; obejmują one tereny pograniczne. Arkusze mapy wykreślano na miejscu w terenie, następnie sporządzono z nich dwie kopie, w nieznanym odstępie czasu. Kopie te wykonane są bardzo starannie, w przeciwieństwie do zróżnicowanego pod tym względem oryginału. Ich rysunek stara się wiernie odpowiadać oryginałowi, tak jeśli chodzi o przedstawienie terenu, jak i o nazwy obiektów. Drobne różnice można znaleźć niekiedy

${ }^{21}$ Tym projektem kieruje Z. Noga. 
w szczegółach ${ }^{22}$. Jedną kopię opatrzono ramkami, w których wypisano nazwy miejscowości, podano numer sekcji i kolumny, wyrysowano podziałkę, a czasami opisano przynależność cyrkularną (Kreis). W tabeli wykreślonej wzdłuż prawej krawędzi arkusza wypisano wszystkie nazwy miejscowości z sekcji, które uzupełniono rubrykami z miejscem na wpisanie liczby mieszczan lub kmieci (Anzahl der Bürger und Baueren), zagrodników i chałupników (Gärtner und Häusler), koni (Pferde). Nie zostały one nigdy wypełnione. Każdy arkusz zawiera ponadto na górnym marginesie numer sekcji poprzedzającej oraz numery sekcji sąsiednich z prawej i lewej strony oraz od dołu. Wskutek dodania ramek i wykazu miejscowości format arkuszy pierwszej kopii powiększono do $70 \times 45 \mathrm{~cm}$ (powierzchnia objęta ramką zewnętrzna), natomiast kopię drugą sporządzono bez marginaliów, co pozwalało, tak jak w przypadku oryginałów, na zestawianie sąsiednich arkuszy ze sobą. Wszystkie mapy, tak kopie jak oryginały, zostały podklejone grubym płótnem.

Czas powstania mapy można ustalić, biorąc pod uwagę przebieg zasadniczych prac terenowych, na lata 1779-1783. Decyzja o kartowaniu kraju zapadła jednak wcześniej, a początek przedsięwzięcia przypada na rok 1775, gdy kierownictwo zdjęcia wojskowego powierzono putkownikowi Johannowi Tobiasowi Seegerowi von Dürrenberg ( $† 1793)$, uprzednio pracującemu przy zdjęciu Górnych Węgier, ustalaniu kordonu na Spiszu i linii zaboru po 1772 r., domniemanemu pomysłodawcy tricku z nieistniejącą rzeką Podhorce, za pomocą którego Austria przesunęta granicę do Zbrucza ${ }^{23}$. Pułkownika Seegera, obarczonego jednocześnie zadaniem demarkacji granicy z Polską, zastępował major Steinbacher, wcześniej zaangażowany przy zdjęciu Śląska, Czech i Górnych Węgier. W ciągu kilku lat, po 1775 r., przeprowadzono prace przygotowawcze, podstawowe obliczenia trygonometryczne na podstawie triangulacji Josepha Liesganiga, wyznaczono podział na sekcje, a także wykonano kartowanie pierwszych obszarów kraju. Dalsze działania wstrzymała prusko-austriacka wojna o sukcesję bawarską (1778-1779). Po jej zakończeniu płk Seeger został odesłany do ustalenia granic uzyskanych nabytków terytorialnych w Innviertel, ppłk Steinbacher objął komendanturę Akademii Wojskowej w Antwerpii, a w Galicji rozpoczęły się najintensywniejsze prace, którymi kierował major, a wkrótce podpułkownik Friedrich von Mieg (1732/1733-1783), dotąd zaangażowany przy zdjęciach Moraw, Siedmiogrodu i Bukowiny oraz demarkacji granicy Galicji na Pokuciu. Chronologia wykonywania mapy przedstawia się następująco:

1. Część najstarsza, wykonana w latach 1775-1778 przez pułkownika Seegera, obejmuje pięć sekcji pogranicza ze Śląskiem pruskim i austriackim. Wykonano wówczas także zdjęcie okolic Lwowa, Śniatynia i Przemyśla.

2. Okręg sądecki, wchodzący w zakres 18 sekcji. Pierwsze zdjęcie tego terenu przygotował płk Seeger już w latach 1770-1771; zachowało się ono w zbiorach Archiwum Wojennego ${ }^{24}$. Zostało włączone do mapy, ale ze względu na inną orientację musiało być w 1783 r. poprawione nową triangulacją i ponownie opracowane, aby można je było połączyć z resztą mapy.

3. Górne dorzecze Dniestru (okolice Sambora i Drohobycza), opracowane w 1781 r. przez podpułkownika Andreasa von Neu (17341803), wcześniej wykonującego zdjęcie Dolnej Austrii. Ppłk Neu zdołał opracować materiał około 20 sekcji, bowiem szybko został odkomenderowany do robót przy zdjęciu Węgier.

4. Pozostała, największa część Galicji na 366 sekcjach została opracowana przez podpułkownika Miega w latach 1779-178325. W drugiej połowie 1779 r. objęto kartowaniem tereny położone na południe od Krakowa oraz duży obszar zajmujący północno-wschodnią ćwierć Galicji, w 1780 r. terytorium środkowe między Bochnią i Łańcutem, w latach kolejnych resztę kraju, przede wszystkim całą część południowo-wschodnią. Zdjęcie zostało ukończone

\footnotetext{
${ }^{22}$ Analiza mapy Węgier w jej części słowackiej wykazała, że różnice między oryginałem a kopiami są minimalne, jednak oryginat jest bogatszy w nazewnictwo, zob. 0. Tomeček, Na margo obsahu exemplárov máp 1. vojenského mapovania, w: Historické mapy. Zborník referátov z vedeckej konferencie, Bratislava 2009, s. 146-149.

${ }^{23}$ W. Konopczyński, Pierwszy rozbiór Polski, Kraków 2010, s. 242.

${ }^{24}$ Kriegsarchiv, B IXa 542.

${ }^{25}$ J. Paldus, Die militärischen Aufnahme, s. 50-51; A. Konias, Kartografia topograficzna Śląska, s. 52.
} 
w maju 1783 r. Nie doczekał tego ppłk Mieg, który zmarł w dniu 12 marca 1783 r. w Sieniawie. Pracami w ich ostatniej fazie kierował kpt. Franz Waldau, wkrótce awansowany na stopień majora i wysłany na Węgry do kartowania kolejnego terenu monarchii.

Większość map zachowała się w dobrym stanie, są jednak arkusze mocno podniszczone. Dotyczy to przede wszystkim pewnej liczby arkuszy początkowych, które są wystrzępione na brzegach, mocno wyblakłe i wytarte, przy krawędziach niekiedy aż do płóciennego podkładu.

Materiał kartograficzny i opisowy ujęty na zdjęciu józefińskim Galicji odznacza się bogactwem i szczegółowością. Mapa oddaje rzeźbę terenu metodą szrafy krzyżowej (góry, wzniesienia, krawędzie dolin rzecznych), oznacza strome i łagodne brzegi rzek, wysokie brzegi stawów, dolinki strumyków, wąwozy, jary, wszelkiego rodzaju pagórki, wały, groble, wydmy. Starannie rysuje elementy hydrografii (rzeki, strumienie, starorzecza, wyspy rzeczne, jeziora, stawy, bagna), pastwiska i łąki (z rozróżnieniem na porośnięte krzakami i podmokłe), lasy (osobno lasy podmokłe), sieć drożną (trakty i drogi pocztowe, drogi kołowe, polne i leśne, przejścia przez bagna, ścieżki piesze i do jazdy wierzchem, mosty murowane i drewniane, brody i przewozy), sieć osadniczą (zabudowę, ulice, świątynie, zagrody wiejskie, dwory, folwarki), uwzględnia zamki i fortyfikacje oraz obwarowania miejskie, urządzenia gospodarcze (młyny, tartaki, warzelnie i składy soli, szyby, pasieki, cegielnie, huty, kamieniołomy), karczmy i zajazdy, krzyże i kapliczki przydrożne, cmentarze i szubienice, prowadzi linię granicy państwowej z oznaczeniem par słupów granicznych. Ponadto skrupulatnie rejestruje nazewnictwo (osad i przysiółków, karczem, rzek i strumieni, lasów i bagien, gór etc.), zazwyczaj oddane fonetycznie i niekiedy zniekształcone (zapisane ze słyszenia przez nienawykłe do mowy polskiej czy ukraińskiej ucho austriackiego oficera).

Pomimo obfitego zasobu zarejestrowanych informacji mapę cechuje zasadniczo harmonia, umiar i ład; przekaz jest jednoznaczny i nie na- suwa zazwyczaj wątpliwości interpretacyjnych. Utrzymanie proporcji, zrównoważenie sygnatur i innych elementów zawartości względem siebie i obowiązującej skali odwzorowania, nieprzeciążenie napisami, nadało zdjęciu józefińskiemu Galicji komunikatywność oraz walory estetyczne.

\section{Opisy}

Topograficzne opisy wojskowe (Militärische Beschreibung) stanowią rozszerzony komentarz sytuacji przedstawionej na arkuszach mapy. Podobnie jak ona pozostawały utajnione do $1864 \mathrm{r}$. Materiał zbierano na miejscu $\mathrm{w}$ trakcie prac. Następnie informacje wpisywano do zeszytów zakładanych dla kolejnych kolumn i zawartych w nich sekcji map. Na końcu każdego zeszytu (kolumny) zestawiano indeks opisanych miejscowości. Zeszyty wypełniane były starannie i czytelnie, kursywą neogotycką. Oprawiano je w tomy. Wszystkie tomy mają podobny wymiar, ok. $40 \times 28 \mathrm{~cm}$.

Opisy mają także zbieżną wewnętrzną konstrukcję, mianowicie układ tabelaryczny, zajmujący szerokość dwóch kart (verso i recto). Ułożone są w następujących rubrykach, licząc od lewej strony:

- nazwa, obok której znajdujemy numer miejscowości w ramach danej sekcji, numer sekcji, umieszczany zwykle przy pierwszej miejscowości na karcie; przy kolejnych miejscowościach jest zazwyczaj detto (jak wyżej),

- odległość od sąsiednich miejscowości; najczęściej wyrażana w czasach przemarszu w godzinach lub ich częściach, tylko sporadycznie w krokach, bardzo rzadko w milach, niekiedy podawane wartości są wzmacniane (stark, czyli „mocna”, „dobra” godzina) lub osłabiane (klein, „mała” godzina),

- solidne budowle, w praktyce budynki murowane; tu zwykle kościoły, klasztory, zamki, pałace i forty, umożliwiające zorganizowanie punktów obserwacyjnych, punktów oporu, składów amunicji itp.; jest to jedna z najrzadziej wypełnianych rubryk.

Kolejne pięć rubryk, zgrupowanych pod jednym wspólnym nagłówkiem (Beschafenheit), przedstawia stan elementów środowiska natu- 
ralnego i infrastruktury komunikacyjnej w następującym porządku:

- wody - w tej rubryce opisywano wszystkie cieki i zbiorniki wodne, podając informacje istotne dla celów wojskowych, a więc szerokość koryta i wysokość brzegów, rodzaj dna (np. żwirowe, kamieniste, muliste), możliwości przeprawy dla ludzi i koni, ciężkiego sprzętu, a więc wozów i artylerii, mosty i kładki, określano stan wód w trakcie suszy i podczas wezbrań oraz ich skutki dla przejezdności dróg,

- lasy - podawano rodzaj drzew (wysokopienne, grubopienne) i lasów (liściaste, iglaste, mieszane),

- łąki i bagna - te pierwsze charakteryzowano jako podmokłe bądź suche, dobre lub liche; tu zwracano uwagę na jakość trawy (paszy) oraz dostępność terenu do celów komunikacyjnych; bagna opisywano przede wszystkim ze względu na możliwość ich sforsowania w różnych porach roku,
- drogi - określano ich rodzaj, od którego zależał stan utrzymania i możliwości trakcyjne w zależności od pogody (piaszczyste, gliniaste lub bagniste, strome), odnotowywano ich kategorię, a więc drogi krajowe, pocztowe, lokalne, wiejskie, leśne; opisywano połączenia z sąsiednimi miejscowościami,

- góry - przedstawiano zwłaszcza dominujące wzniesienia, mogące służyć za punkty obserwacyjne bądź orientacyjne, nachylenie stoków i ich pokrycie.

Ostatnia, nie zawsze wypełniana rubryka to uwagi. Niekiedy jednak jest ona wypełniona bardzo obszernie, na przykład wskazówkami o możliwościach wykorzystania lokalnych warunków terenowych w działaniach taktycznych.

Wpisy są bardzo zróżnicowane pod względem objętości. Przy niektórych miejscowościach pewne rubryki są puste. Czasami brak wpisu zaznaczany jest znakiem „Ø”. Obszerny

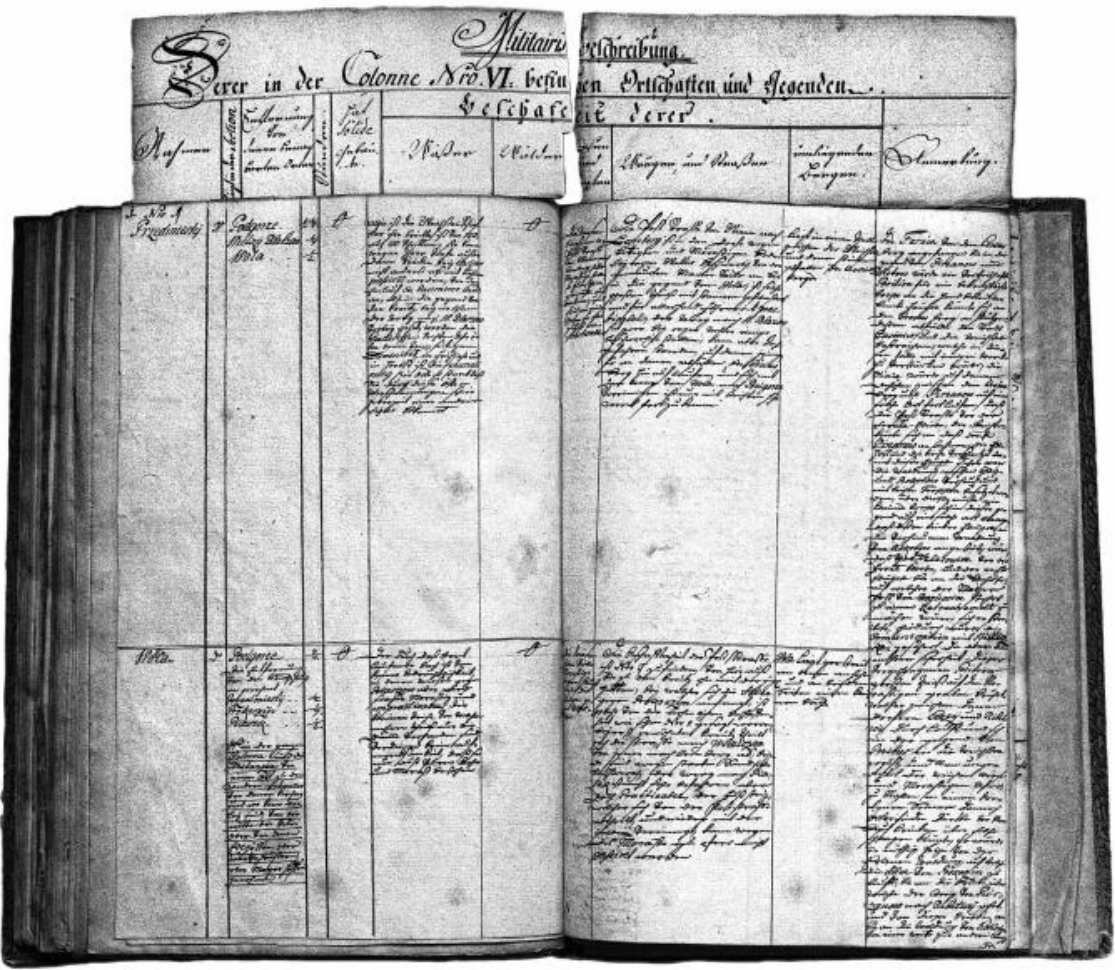

Ryc. 4. Strony tomu I opisów wojskowych, z rozłożoną zakładką zawierającą tytuły rubryk (Kriegsarchiv, B IXa 390). Opis Przedmieścia i Woli Duchackiej koło podkrakowskiego Podgórza, kolumna VI, sekcja 31, fot. A. Janeczek 
wpis w jednej, dosyć wąskiej rubryce sprawia, że dana miejscowość zajmuje w tabeli stosunkowo dużo miejsca; z reguły jednak karta zawiera wpisy średnio dla kilku miejscowości.

\section{Zasady edycji}

\section{Konstrukcja podziału na tomy}

Zasadniczym problemem przy edycji map i towarzyszących im opisów był sposób prezentacji tego olbrzymiego materiału, wymagającego podzielenia na tomy. W pierwszym rzędzie chodziło o to, aby skorelować liczbę map tworzących tom z objętością tekstu odpowiadających im opisów, bez tego bowiem niemożliwe było zaplanowanie zakresu edycji materiału w pierwszym i następnych tomach. Było to osiągalne dopiero po odczytaniu rękopisu opisów do wszystkich sekcji. Drugą kwestią wymagającą rozstrzygnięcia było ustalenie porządku komponowania zawartości tomów. Wypełnianie ich sekcjami w porządku numerowania arkuszy zostało od razu odrzucone jako sprzeczne $\mathrm{z}$ interesem użytkownika; wprawdzie tomy zachodniej części utrzymałyby wewnętrzną zwartość, to jednak tomy części środkowej, a zwłaszcza wschodniej, musiałyby składać się z sekcji tworzących wąski słup, rozciągnięty na przykład od Zamojszczyzny po Huculszczyznę. Podział na tomy warunkowany był w dużej mierze nieregularnym kształtem terytorium Galicji, w części zachodniej wydłużonym równoleżnikowo, zaś we wschodniej - południkowo. Rozciągało się ono od źródeł Wisły na zachodzie, po Zbrucz na wschodzie, początkowo niewysokim pasem, lecz od kolumny XII południowa granica gwałtownie skręcała wzdłuż łuku Karpat w kierunku Bukowiny i Mołdawii. Przyjęto zatem porządek według układu regionalnego, chociaż jego wydzielenie nastręczało wielu trudności. Stosowano zasadę dzielenia mapy na tomy po liniach prostych (zob. ryc. 5). Jednocześnie starano się to robić tak, by - nie naruszając tej zasady - nie

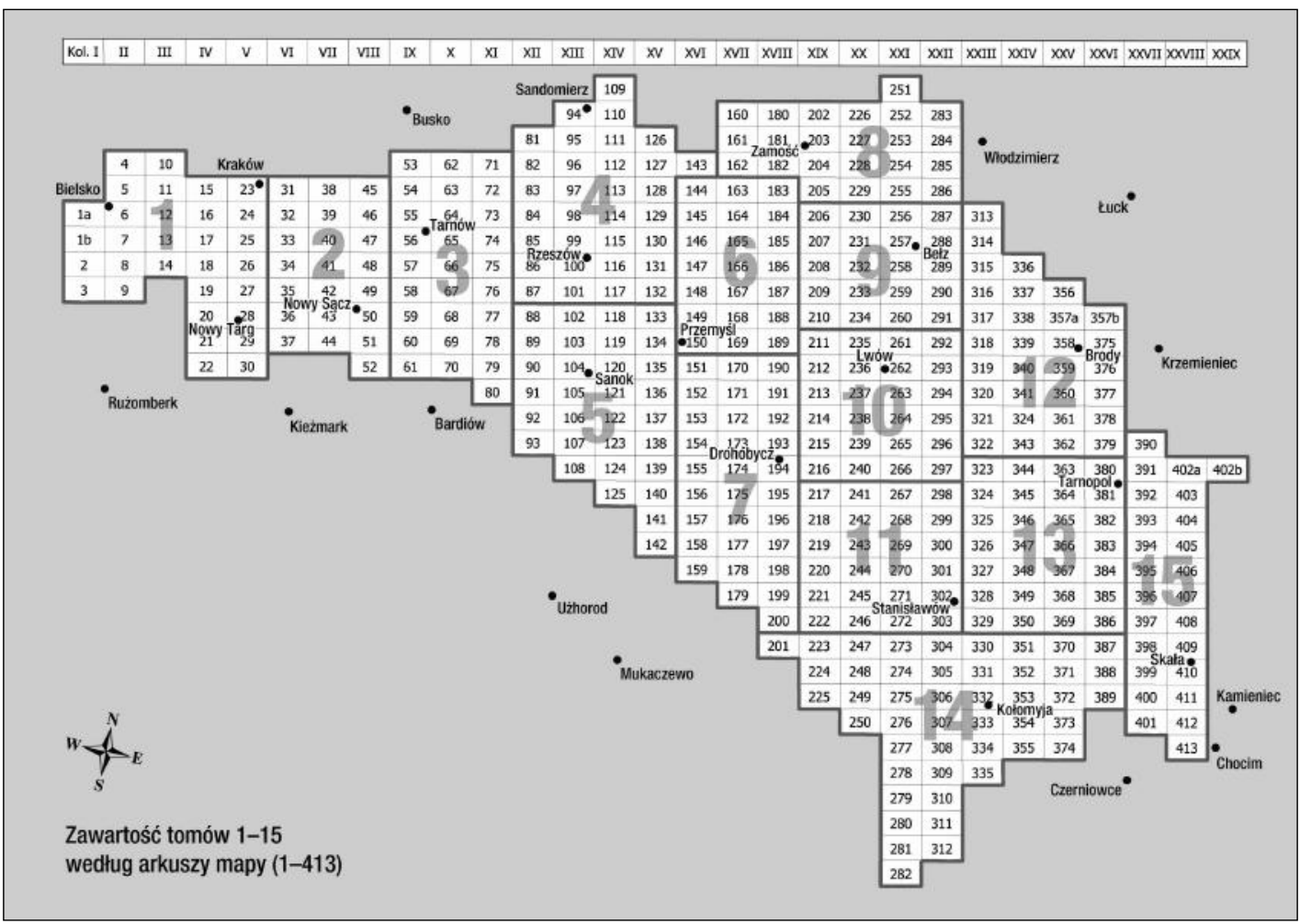

Ryc. 5. Schemat podziału arkuszy mapy na tomy edycji, oprac. A. Janeczek 
dzielić jednorodnych obszarów staropolskich jednostek osadniczych i administracyjnych między poszczególne tomy $\mathrm{w}$ przypadkowy sposób. Stosunkowo łatwo udało się pomieścić dawne województwo krakowskie w trzech tomach, chociaż trzeci tom wkracza już na ziemie dawnego województwa sandomierskiego. Tom czwarty, obejmujący pozostałą część województwa sandomierskiego, mieści w sobie również dziesięć sekcji sąsiedniej ziemi przemyskiej. Podobnie udało się skomponować tomy obejmujące w większości ziemie sanocką i przemyską, trzon województwa bełskiego, w trzech tomach zawrzeć obszar ziemi lwowskiej, w kolejnym środkową część ziemi halickiej, a w następnych region wschodniokarpacki i nadzbruczański. Dla badacza Galicji staropolskie podziały administracyjne nie mają takiego znaczenia jak podziały ówczesne, dla innych z kolei ważne jest również osadzenie mapy w dzisiejszych realiach administracyjnych. Wszystkim tym oczekiwaniom starano się wyjść naprzeciw w ten sposób, że do każdego tomu wyrysowano odpowiedni fragment mapy Galicji z układem arkuszy i naniesionymi nań podziałami administracyjnymi w czterech przekrojach czasowych.

Ostatecznie sposób prezentacji całego źródła rozwiązano w ten sposób, że materiał rozmieszczono w piętnastu podobnej objętości tomach, dzieląc mapę na możliwie jak najbardziej zwarte fragmenty. Każdy tom składa się z dwu woluminów. W jednym zostały zamieszczone faksymilia map, w zależności od objętości źródła tekstowego, w liczbie od 20 do 46 map. Drugi wolumin zawiera teksty opisów w języku niemieckim $\mathrm{z}$ równoległym tłumaczeniem na język polski, komentarze do opisów, dalej indeks nazw na mapie, czyli tzw. toponimię sekcji, indeks łączny map i opisów oraz objaśnienie znaków i napisów mapy.

\section{Edycja map}

Do reprodukcji wybrano oryginalne arkusze mapy, a nie ich kopie, mimo że te ostatnie są wykonane staranniej. Zadecydował o tym właśnie walor oryginału, mapy sporządzanej na miejscu kartowanego terenu, z wszystkimi pozytywnymi tego konsekwencjami. Ponadto zaważył tu fakt, że dotychczas polscy badacze dysponowali częstokroć kopiami, nie wiedząc niekiedy o istnieniu oryginału. Dla porównania $\mathrm{z}$ oryginałem do każdego tomu dodano więc po kilka arkuszy kopii. W wyborze kierowano się zasadą, by załączyć kopie najbardziej zniszczonych i mniej czytelnych arkuszy oryginalnych. Napisy na niektórych (na szczęście nielicznych) sekcjach często są wykonane tak niestarannie, że nie sposób ich odczytać bez pomocy kopii; była to kolejna przesłanka za ich selektywnym uwzględnieniem w edycji. W przypadku dwóch arkuszy (251 i 282, pierwszy i ostatni z kolumny XXI) egzemplarze oryginału zaginęły, w ich miejsce wzięto do reprodukcji arkusze kopii pierwszej.

Na marginesy reprodukowanych sekcji mapy naniesiono metryczkę arkusza z numerami kolumn i sekcji, gdyż oryginały, całkowicie wypełnione rysunkiem, ich nie mają. Znalazły się tu również oznaczniki podziału arkusza na osiem sektorów (od A1 do D2), które wprowadzono dla dokładniejszego określenia położenia obiektów, podawanego w części inwentaryzującej toponimię mapy oraz $\mathrm{w}$ indeksie. Zamieszczono ponadto podziałkę liniową.

\section{Edycja opisów}

Zasadniczą ideą przyświecającą edycji opisów jest $\mathrm{z}$ jednej strony zamiar uchwycenia specyfiki i odmian języka używanego przy przygotowaniu tego źródła, odzwierciedlającego i dokumentującego poziom wykształcenia, przez to status społeczny i formację kulturową autorów, ich stopień znajomości języka niemieckiego oraz jego odmian, mogący wskazywać na pochodzenie autorów z różnych obszarów funkcjonowania języka niemieckiego czy też spoza nich $^{26}$. Z drugiej strony celem tej edycji źródłowej - jak każdej innej - jest udostępnienie źródła odbiorcy w sposób możliwie czytelny i przejrzysty. Innych trudności przysporzyło

\footnotetext{
${ }^{26}$ Pierwsza próba badawcza z tego zakresu: I. Nöbauer, „Höchst vorläufige Bemerckungen zu dero Sprachkunst dero Josephinischen Landesaufnahme Galizien und Lodomerien" - Zu den sprachlichen Besonderheiten der so genannten Miegkarte , , Jahrbuch des Wissenschaftlichen Zentrums der Polnischen Akademie der Wissenschaften in Wien", 3 (2012), s. 43-58.
} 
przełożenie formy tabelarycznej opisów, nieefektywnej w zastosowaniu w edycji drukowanej, na tekst ciągły. Wszystkie te zabiegi musiały też brać pod uwagę oczekiwania i potrzeby różnych odbiorców źródła ${ }^{27}$.

Przyjęta ostatecznie metoda jest wypadkową tych czynników i swoistym kompromisem między nimi. Tekst, podobnie jak w przypadku wcześniejszych tego typu edycji (słoweńskiej i chorwackiej), publikowany jest równolegle - w języku źródła (niemieckim) oraz w tłumaczeniu na język polski. W przypadku tomów obejmujących tereny współczesnej Ukrainy dołączone zostanie tłumaczenie na język ukraiński. Tekst jest zgodnie z układem źródła podzielony na kolumny, sekcje, a w ich ramach - na poszczególne miejscowości. W ramach miejscowości następuje po kolei treść kolejnych rubryk, przy czym pomijane są te, które zostały niewypełnione dla danego miejsca. Pominięto też rubrykę z numerem bieżącej sekcji (jest ona każdorazowo umieszczona w żywej paginie).

W odróżnieniu od tych uproszczeń przejęto zasadę możliwie wiernego zachowania języka, którym posługiwali się sporządzający źródło wojskowi. Dotyczy to przede wszystkim pisowni i wszystkich jej niekonsekwencji, gramatyki, zasadniczo także pisowni łącznej i rozłącznej. Decyzja ta nawiązuje do wyraźnej przy wydawaniu tekstów historycznych w języku niemieckim dążności do stosunkowo niewielkiej ingerencji, by umożliwić badania nad tekstem także językoznawcom ${ }^{28}$. W przypadkach wątpliwych, gdy oryginalny zapis słowa mógłby utrudnić jego zrozumienie, ewentualne uzupełnienia wprowadzano $\mathrm{w}$ nawiasie kwadratowym. Podobne uzupełnienia wprowadzano niekiedy także w przypadku, gdy słowo było nieczytelne ze względu na zbyt głębokie wszycie karty (dotyczy to przede wszystkim rubryki leśnej i łąkowo-bagiennej). Przy bardzo odbiegających od normy zapisach stosowano dla potwierdzenia prawidłowości odczytu znak „[!]”. Przypisy dotyczące krytyki źródła, zredagowane wedle zasad polskiej instrukcji wydawania źródeł nowożytnych ${ }^{29}$, wprowadzono tylko w niezbędnym zakresie (podkreślenia, ewident- ne późniejsze uzupełnienia itp.), rezygnując $\mathrm{z}$ zaznaczania wszystkich poprawek w tekście, zakładając, że są one efektem korekty sporządzanego czystopisu. Ingerencje modernizujące (i porządkujące) dotyczą w zasadzie tylko dwóch obszarów: pisowni rzeczowników $\mathrm{z}$ wielkiej litery oraz interpunkcji.

Przy tłumaczeniu tekstu źródła na język polski starano się zachować możliwie dużą wierność, pozwalającą na korelację publikowanych obok siebie tekstów. Jeśli to było tylko możliwe, starano się odwzorować strukturę tekstu niemieckiego. Niezbędne dla lepszego zrozumienia tekstu uzupełnienia wprowadzano w nawiasie kwadratowym. Należy wyrazić nadzieję, że przyjęta metoda $\mathrm{z}$ jednej strony pozwoli uchwycić specyfikę źródła, z drugiej strony ułatwi jego percepcję. Te same założenia będą respektowane przy osobnym tłumaczeniu na język ukraiński, które jest planowane dla dalszych tomów edycji.

\section{Aparat edycji}

Poza wstępem źródłoznawczym i prezentacją zasad przyjętych przez wydawców, opracowaniami kreślącymi tło historyczne, przedstawiającymi okoliczności powstania mapy oraz dającymi jej charakterystykę kartograficzną, edycja zostanie zaopatrzona w komentarze i objaśnienia, klucz znaków mapy, napisów i ich skrótów, mapy skorowidzowe, wykazy toponimii oraz indeks, wspomagające pracę ze źródłem.

\section{Objaśnienia i komentarze do opisów wojskowych}

Tekst opisów, sam w sobie zawierający bogactwo informacji, opatrzono tylko najbardziej niezbędnymi komentarzami ułatwiającymi lekturę, odsyłając do podstawowych opracowań encyklopedycznych, słownikowych, katalogowych lub monografii regionalnych. Tak więc objaśniano:

\footnotetext{
${ }^{27}$ Zasady edycji części opisowej przygotował B. Dybaś, który wraz $z$ Ł. Walczym wykonat gros prac przy odczytaniu, skolacjonowaniu i przettumaczeniu tekstu na język polski.

${ }^{28}$ G. Müller, Empfehlungen zur Edition frühneuzeitlicher Texte, „Archiv für Reformationsgeschichte“, 72 (1981), s. 299-315.

${ }^{29}$ Instrukcja wydawnicza dla źródet historycznych od XVI do połowy XIX wieku, red. K. Lepszy, Wrocław 1953.
} 
- nazwy osad, jeśli noszą dziś inną nazwę lub zmieniły swój status, wszystkie wzmiankowane obiekty o charakterze militarnym, użytkowym czy kultowym, jak zamki, dwory, kościoły, klasztory, znaczniejsze budowle, karczmy i młyny z własnymi nazwami,

- wszystkie rzeki, strumienie, potoki i stawy wymienione w tekście z nazwy oraz te, których nazw nie podano,

- inne obiekty fizjograficzne z własną nazwą, jak lasy, polany itp., dziś już nieistniejące lub niezidentyfikowane, jeśli tylko było to możliwe.

Nie objaśniano gór, szczytów górskich oraz wzniesień opatrzonych własnymi nazwami, chyba że zmieniły nazwę na inną, funkcjonującą dzisiaj i dającą się zidentyfikować na mapie. W zasadzie bez objaśnienia pozostawiono też nazwy obiektów fizjograficznych, których nie dało się zidentyfikować na współczesnej mapie topograficznej.

\section{Klucz znaków mapy}

i jej napisów objaśniających

Zdjęcie józefińskie Galicji posługuje się bogatym zestawem umownych znaków graficznych i skrótów literowych, jednak pozbawione jest klucza objaśniającego przypisane im treści znaczeniowe. Brak również innych elementów legendy, oznaczenia podziałki (umieszczono ją tylko na kopiach) oraz kierunku orientacji. Pośród zachowanych niemal w komplecie sekcji mapy nie ma osobnego arkusza tytułowego, nigdzie nie umieszczono kartusza ani żadnych marginaliów z informacjami opisowymi. Własnej tablicy sygnatur brakuje nie tylko

${ }^{30} \mathrm{~J} . \mathrm{G}$. Tielke, Unterricht für die Officiers, die sich zu Feld-Ingenieurs bilden, oder doch den Feldzügen mit Nutzen beywohnen wollen, durch Beyspiele aus dem letzten Kriege erläutert, und mit nöthigen Plans versehen, Dresden 1769 (wyd. 2, Dresden 1774; wyd. 3, Dresden 1779; wyd. 4, Wien 1785; kolejne edycje 1795, 1818); L. Voch, Die Kunst Situationsplane mit Hülfe einer besonders dazu verfertigten Schreibtafel und auf andere verschiedene Arten aufzunehmen und zu zeichnen, Augsburg 1774 (wyd. 2, Augsburg 1781); F. Landerer, Gründliche Anleitung Situations-Plane zu zeichnen. Zum Gebrauche der k. k. Ingenieur-Akademie, wie auch jener, die sich den Mappirungs-Geschäften widmen, Wien 1782 oraz Wien 1783 (kolejne edycje 1796, 1805, 1812); J.F. Keferstein, Anfangsgründe zu praktisch geometrischen Zeichnungen und Vermessungen, die zur Anfertigung und Abzeichnung der oeconomischen, militärischen und geographischen Charten und zur Kenntniß des verschiedenen Meilen-, Ruthen-, w przypadku mapy Galicji, nie ma jej także wiele innych map zdjęcia józefińskiego.

Widoczny zakres niekonsekwencji, różnorodność niektórych oznaczeń graficznych i stosowanie odmiennych symboli do przedstawienia takich samych obiektów może wskazywać, że ścisłej i szczegółowej, obowiązującej na zdjęciu normy prezentacji nie wprowadzono, a jedynie stosowano się do ogólnych konwencji rysowania i kolorowania, ówcześnie zalecanych w wojskowych pracach kartograficznych oraz do wzorcowych wskazówek, wydawanych przez Kwatermistrzostwo Sztabu Generalnego. Zauważalne na mapie warianty sygnatur, różnice tonalne nałożonego koloru, cechy indywidualne rysunku, a zwłaszcza jego różna staranność, to skutek prowadzenia prac w kilkunastu zespołach, w których zaangażowani byli oficerowie wykazujący się różnym poziomem umiejętności i uzdolnień rysunkowych. Pomimo tego generalny styl prezentacji wykazuje cechy wspólne dla całej mapy i nie odbiega od maniery graficznej innych map zdjęcia józefińskiego.

Klucz typowych, użytych znaków oraz wykaz skrótów zamieszczonych na mapie, został zrekonstruowany na podstawie podręczników oraz instrukcji kartograficznych z epoki, tj. z ostatniej ćwierci XVIII w..$^{30}$, zestawienia symboli i skrótów stosowanych na austriackich mapach topograficznych w XIX w., sporządzonego przez podputkownika Josefa Zaffauka (1833-1911), profesora Technicznej Akademii Wojskowej w Wiedniu ${ }^{31}$, opracowań z zakresu historii kartografii ${ }^{32}$ oraz analizy treściowej mapy Galicji. Porównawczo wykorzystano dotychczasowe edycje zdjęć jó-

Fuß-, und Zoll-Maaßes nötig sind, Leipzig 1778; Bettlack, Anleitung, Situations-Plane zu zeichnen. Zum Gebrauch der Churfl. Sächsischen Ritter-Akademie entworfen und zusammen getragen vom Hauptmann Bettlack, Lehrer der Fortifikation, Dresden 1784; J. von Mackiewicz, Anweisung Situationsplane zu zeichnen und zu illuminiren, Prag 1798 (kolejne wyd. Prag 1806, 1819, 1821).

${ }^{31} \mathrm{~J}$. Zaffauk, Signaturen in- und ausländischer Plan- und Kartenwerke, nebst Angabe der in Karten und Plänen am häufigsten vorkommenden Worte und Wort-Abkürzungen in 12 Sprachen, 2., vermehrte Auflage, Wien 1889

2 J. Paldus, Die militärischen Aufnahmen, s. 20; L. Sawicki, Obristen Anton Freiherr Mayer von Heldensfeld topographische Aufnahme Westgalliziens, s. 62-70; A. Konias, Kartografia topograficzna, s. 58-66. Próbę odtworzenia klucza mapy Galicji podjęła również H.P. Petryšyn, Karta F. fon Miga, s. 19-23, 33-37. 
zefińskich dla innych krajów (Słowenii i Chorwacji, a zwłaszcza Węgier i Niderlandów) oraz zamieszczone w nich informacje o właściwych tamtym mapom znakach kartograficznych ${ }^{33}$, a także legendę józefińskiej mapy Siedmiogrodu. Objaśnieniu użytych na mapie znaków i napisów oraz rozwiązaniu ich skrótów, jako kluczowi do prawidłowego odczytania treści mapy, poświęcono odrębny artykuł części wstępnej.

\section{Mapy skorowidzowe}

Pomocą $\mathrm{w}$ posługiwaniu się mapą miał być załączony do niej skorowidz, prezentujący układ wszystkich sekcji józefińskiego zdjęcia Galicji. Zachowały się trzy wersje oryginalnej mapy szkieletowej. Pierwsza z nich to roboczy, niestarannie wykonany pierworys, sporządzony w kwietniu 1781 r. w Sieniawie, głównej kwaterze podpułkownika Miega. Nosi tytuł: Skellet und Entheilung der Mappirungs-Arbeiten in Gallicien i oddaje stan prac pomiarowych do tego czasu. Przy poszczególnych kolumnach wpisano nazwiska oficerów, którzy kartowali dany obszar. Drugi skorowidz to czystorys sporządzony w ostatniej fazie robót lub już po ich zakończeniu, stanowiący końcowy raport z prac pomiarowych w Galicji, przeprowadzonych w latach 1779-1782 pod kierunkiem podpułkownika Miega; jego nazwisko widnieje wpisane u dołu tego raportu. Nosi on tytuł Summarischer Rapports-Plan deren Gallicischen Mappirungs-Arbeiten Erklärung. Poza układem sekcji rejestruje on również etapy przygotowywania zdjęcia kraju, oznaczając czterema kolorami kolejno kartografowane terytoria. Wyszczególniono tutaj także nazwiska wszystkich oficerów Kwatermistrzostwa Sztabu Generalnego i oficerów pułkowych wykonujących pomiary, ale tylko sumarycznie. Faksymile tego skorowidza włączono do edycji. Trzecia plansza zbiorcza, zatytułowana Esquelette der Gallicischen Carte, to prosty schemat układu arkuszy, zawierający oznaczenia ważniejszych miejscowości i sieć wodną oraz granice Galicji. Jest on niedatowany, podpisany został przez kapitana Franza Waldau (a więc przed 2 sierpnia 1783 r., kiedy otrzymał on awans na majora) $)^{34}$, następcę podpułkownika Miega w ostatniej fazie prac, przypadającej na wiosnę $1783 \mathrm{r}$.
Praktyczna przydatność oryginalnych skorowidzów jest jednakże ograniczona. Kartografowie austriaccy zorientowali mapę nie na północ geograficzną, ale zastosowali orientację magnetyczną, zdecydowanie preferowaną w ówczesnej kartografii wojskowej. W wyniku tego arkusze mapy są w stosunku do dzisiejszych map topograficznych obrócone o wartość kąta między północą geograficzną a magnetyczną. Wartość deklinacji magnetycznej dla okolic Lwowa z epoki zdjęcia józefińskiego można szacować na ok. $13^{\circ} . \mathrm{Z}$ tego powodu oryginalna mapa szkieletowa, również zorientowana na biegun magnetyczny, jest kłopotliwa w praktycznym wykorzystaniu. Co gorsza, jej wartość w roli przewodnika po całej mapie osłabiają liczne niedokładności i spore deformacje.

$\mathrm{Z}$ tych względów konieczne stało się opracowanie nowych skorowidzów ${ }^{35}$. W celu pokazania rzeczywistego ułożenia sekcji siatkę mapy Galicji nałożono na podkład mapy dwudziestowiecznej. Podkładem były mapy w skali 1:300 000, wydawane w latach 1925-1937 przez Wojskowy Instytut Geograficzny. Z mapy podkładu uwzględniono sieć rzeczną (na poziomie generalizacji charakterystycznej dla mniejszej skali, 1:700 000 - 1:1 000000$)$ i niektóre punkty osadnicze, konieczne przy rekonstrukcji dawnych podziałów administracyjnych oraz miejscowości będące głównymi na danej sekcji mapy Galicji, czyli tzw. godła sekcji. Krawędzie poszczególnych sekcji mapy wykreślono w ten sposób, że na podkład naniesiono punkty przecięcia się tych krawędzi, a następnie połączono je liniami prostymi. Potem dokonano weryfikacji przebiegu krawędzi sekcji na podkładzie z ich przebiegiem na mapie józefińskiej. Przebieg granicy Galicji został zdjęty bezpośrednio z przeskalowanych oryginalnych sekcji mapy józefińskiej. W miejscach, w których

\footnotetext{
${ }^{33}$ Carte de Cabinet de Pays-Bas autrichiens, t. 1, Légende; A. Jankó, Az első katonai felmérés (1763-1785), tablica znaków: „Az I. katonai felmérés jelei", wg A. Borbély, J. Nagy, w: Az első katonai felmérés: Magyar Királyság. Dodatkowo uwzględniono wstępy w edycjach słoweńskiej (Slovenija na vojaškem zemljevidu) i chorwackiej (Hrvatska na tajnim zemljovidima).

${ }^{34} \mathrm{~J}$. Paldus, Die militärischen Aufnahmen, s. 10; A. Jankó , An outstanding person of the 1st military survey: Mihály Lajos Jeney, "Térképtudományi Tanulmányok", 13 (2006), s. 206.

${ }^{35}$ Zajął się tym J. Szyszka z Instytutu Historii PAN.
} 


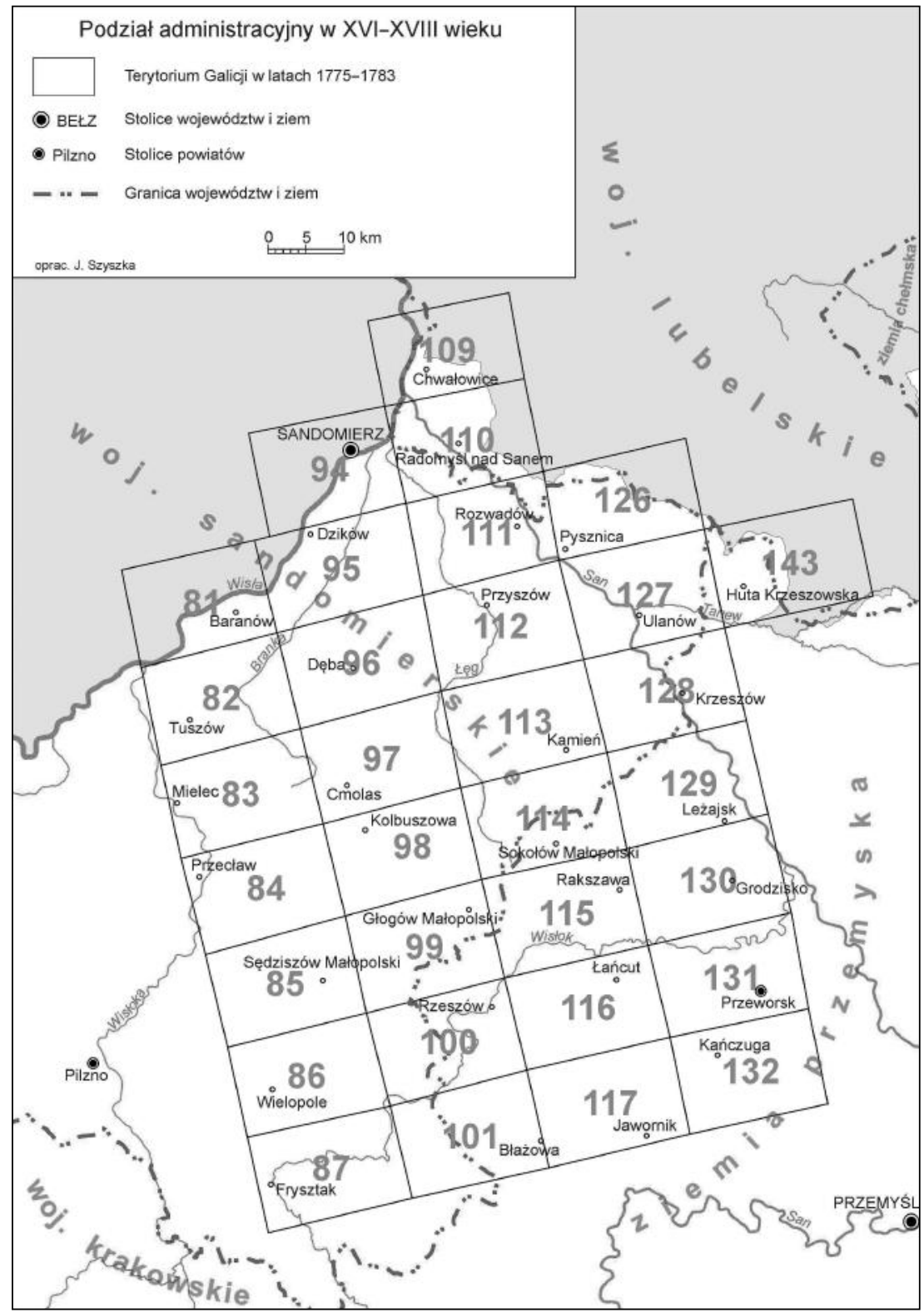

Ryc. 6. Przykładowa mapa skorowidzowa do tomu 4, prezentująca układ publikowanych w nim arkuszy w kontekście podziałów terytorialnych doby staropolskiej, oprac. J. Szyszka

nie udało się związać tych sekcji z podkładem, zwłaszcza w terenie górzystym i pokrytym gęstym lasem, przebieg granicy był weryfikowany za pomocą mapy Liesganiga.

Powyższa mapa wykorzystana została następnie do wkreślenia granic politycznych i admini- stracyjnych na obszarze stanowiącym terytorium Galicji w czterech przekrojach czasowych: według stanu z XVI-XVIII w., ok. 1790 r., 1934 r. i współczesnego. Były one zdejmowane $\mathrm{z}$ odpowiednio przeskalowanych map pomocniczych, dostarczających informacji o przebiegu 
granic $^{36}$. W rezultacie każdy tom wydawnictwa zostanie zaopatrzony w cztery mapy przeglądowe, prezentujące publikowane w nim arkusze mapy w kontekście zmieniających się podziałów terytorialnych, od struktury staropolskiej, sieci galicyjskich cyrkułów i międzywojennych województw, do obecnej (polskie województwa, ukraińskie obwody). Usprawni to zorientowanie się w zawartości poszczególnych tomów i ułatwi dotarcie do odpowiedniego arkusza mapy, w zależności od potrzeb odniesienia się do sytuacji politycznej i podziałów administracyjnych różnych epok.

\section{Wykazy toponimii mapy}

W wykazach toponimii sekcji zinwentaryzowano wszystkie nazwy własne (miejscowe, nazwy dworów, folwarków, obiektów gospodarczych i fizjograficznych), znajdujące się na poszczególnych sekcjach oryginału mapy. Ponadto zindeksowano pierwszą kopię, opatrzoną tabelką z wykazem miejscowości, w celu wychwycenia ewentualnych różnic w opisie obiektów między obydwoma egzemplarzami. Każdy arkusz mapy podzielono na 8 okien (sektorów) opisanych kombinacją cyfr i liter: A1, A2, B1, B2, C1, C2, D1, D2. W przypadku arkuszy ponadformatowych fragmenty wykraczające poza moduł oznaczono, poszerzając numerację w odpowiednim kierunku, jak na przykład A0 czy D3.

Nazwy na mapie czytano i ewidencjonowano, tak jak czyta się tekst książki, od lewej do prawej strony okna, i w takiej też kolejności zamieszczono je $\mathrm{w}$ indeksie pod odpowiednim numerem, poświęcając układ alfabetyczny. Dzięki temu szybciej można zlokalizować opisany na mapie obiekt. Na pierwszym miejscu występuje zawsze zapis nazwy na oryginale, a po ukośniku nazwa z kopii, o ile różni się od zapisu

\footnotetext{
${ }^{36}$ Dla naniesienia granic staropolskich województw i ziem wykorzystano: A. Jabłonowski, Atlas historyczny Rzeczypospolitej Polskiej wydany z zasiłkiem Akademii Umiejętności w Krakowie, [t. 1]: Epoka przełomu z wieku XVI-ego na XVII-sty. Dział II-gi. „Ziemie Ruskie” Rzeczypospolitej, Warszawa-Wiedeń 1889-1904; Atlas historyczny Polski. Mapy szczegótowe XVI wieku. Województwo sandomierskie w drugiej połowie XVI wieku, red. W. Pałucki, Warszawa 1993; Atlas historyczny Polski. Mapy szczegótowe XVI wieku. Województwo krakowskie w drugiej połowie XVI wieku, red. H. Rutkowski, Warszawa 2008; A. Janeczek, Osadnictwo pogranicza polsko-ruskiego. Województwo betskie od schyłku XIV do początku XVII w., Wrocław
}

oryginału, np. Targanyca/Targanica. Jeśli na kopii brak nazwy, która znajduje się na oryginale, po ukośniku pojawi się cyfra zero, np. Babice/0 i odwrotnie w sytuacji, gdy brak jest nazwy na oryginale. Każda nazwa z mapy została, o ile to było możliwe, zidentyfikowana. Obiekty zaginione lub niezidentyfikowane opatrzono pytajnikiem. Wszystkie rzeki, potoki i strumienie identyfikowano podając nazwę większej rzeki, której są dopływami. Nazwy miejscowości i innych obiektów, które nie są wzmiankowane w opisach, opatrzono komentarzami dotyczącymi ich obecnego statusu i przynależności administracyjnej. Pozostałe obiekty objaśniono wyłącznie w przypisach do źródła tekstowego.

Każda nazwa z mapy jest zapisana kursywą, następnie podany jest czcionką prostą status punktu osadniczego lub rodzaj obiektu fizjograficznego (np. wieś, przysiółek, folwark, młyn, rzeka, góra, polana, las itp.) oraz jego nazwa dzisiejsza. Status osad starano się zróżnicować w zależności od ich charakteru, np. wieś lub przysiółek. Nie zawsze było to możliwe. Nie uwzględniono jednak zróżnicowania charakteru cieków wodnych, występującego zarówno na mapie (Bach, Fluss), jak i we współczesnym języku polskim (rzeka, potok, strumień), określając je wszystkie mianem rzeki.

\section{Indeks}

Indeks obejmuje wszystkie nazwy własne: miejscowe i fizjograficzne oraz nieliczne osobowe, występujące w opisach wojskowych, przypisach rzeczowych do nich i na arkuszach mapy, te ostatnie zebrane i objaśnione w wykazach toponimii sekcji ${ }^{37}$. Winien on służyć do szybkiego odnalezienia szukanego obiektu z jednej strony, z drugiej zaś do identyfikacji obiektów

1991, mapy pod opaską. Podziały terytorialne porozbiorowe wkreślono według: J. Liesganig, Regna Galiciae et Lodomeriae Josephi Il et M[ariae] Theresiae aug[ustorum] iussu methodo astronomicotrigonometrica, nec non Bukovina geometrice dimensa, 1:288 000, [Vindobonae 1790]; Topographische Karte von Ostgalizien und Lodomerien in 14. Sectionen nach den neuesten Aufnahmen, hrsg. von dem Galizischen Strassenbaudirektor Gross, ok. 1:144 000, Wien [ok. 1815]. Granice województw II Rzeczypospolitej zaczerpnięto z tzw. milionówki Wojskowego Instytutu Geograficznego (Mapa Rzeczypospolitej Polskiej, 1:1 000 000, Warszawa 1934).

${ }^{37}$ Zasady konstruowania indeksu opracowali W. Bukowski i Z. Noga. 
napotkanych w tekście lub na mapie, bez potrzeby podejmowania czasochłonnych poszukiwań, chyba że identyfikacja wydawców jest błędna czy wątpliwa. Indeks scala zatem dwa różne zbiory, mianowicie nazwy ze źródła tekstowego oraz toponimy z mapy, łącząc je w układzie alfabetycznym, ale z zachowaniem ich odrębności. Dla rozróżnienia, z którego z tych obu zasobów pochodzi zapis, nazwy ze źródła tekstowego zostały podane czcionką grubą, zaś nazwy z mapy kursywą.

Każda forma zapisu nazwy (miejscowości, rzeki, góry, lasu, folwarku, karczmy, młyna, dworu lub innego obiektu noszącego nazwę własna) użyta w źródle tekstowym została odnotowana w indeksie jako odsyłacz do dzisiejszej nazwy, np. Andrichow zob. Andrychów. Toponimów z mapy nie odsyłano do hasła głównego, lecz identyfikowano podając od razu ich nazwę urzędową, np. Andrzichow vel Jendrzichow - Andrychów. W przypadku, gdy punkty osadnicze lub obiekty fizjograficzne odnotowane w źródle dziś już nie istnieją, albo nie zostały zidentyfikowane, odsyłano do dawnej nazwy zachowanej w polskim zasobie leksykalnym. Nazwy miejscowości, zarówno tych dziś istniejących, jak i nieistniejących, zaginionych albo niezidentyfikowanych, zostały wyróżnione wersalikami. Nazwy obiektów fizjograficznych, jak np. rzeki i góry, podano małą czcionką zwykłą.

Nazwa w dzisiejszym brzmieniu jest hasłem głównym, które zbiera w nawiasie wszystkie występujące w źródle tekstowym i na mapie zapisy tej nazwy, od których odesłano pod to właśnie hasło. Dalej podano charakter punktu osadniczego lub obiektu fizjograficznego, np. wieś, folwark, rzeka itp., w przypadku osad lokalizację, przez określenie obecnej polskiej przynależności powiatowej lub ukraińskiej rejonowej, numer strony w tekście źródłowym i numer arkusza oraz pola na mapie, gdzie dany obiekt występuje, np. Hałcnów (Ahlsen, Alsem, Alsen, Haussnow, Pohlnisch Alsen), wś (biel.) 24, 25; 5B2.

\section{Spodziewane efekty i dalsze zamierzenia}

Edycja dobrej technicznie repliki mapy z archiwum wiedeńskiego, o czytelności dorównującej oryginałowi, wraz z towarzyszącymi jej opi- sami dotąd w ogóle nieznanymi, pozwoli udostępnić ten jedyny w swym rodzaju materiał i wydatnie, w sposób przełomowy, rozszerzyć zakres jego wykorzystania - przede wszystkim wśród profesjonalistów z wielu dziedzin humanistyki i nauk geograficzno-przyrodniczych, ale również wśród regionalistów i krajoznawców, w środowiskach samorządowych, wśród miłośników swych „małych ojczyzn” i wszystkich zainteresowanych historią rodzimą i rodzinną. Tym ostatnim da możność, dzięki swojej dokładności, przeżycia swoistej „wycieczki w czasie", rozpoznania rodzinnych okolic w kształcie sprzed 230 lat, zidentyfikowania charakterystycznych miejsc i obiektów, naocznego uświadomienia zmian. Dlatego edycja może mieć walor popularyzatorski i kształcący, również w edukacji szkolnej. $Z$ tych samych względów publikacja może być impulsem do podjęcia nowych badań naukowych, dotyczących lokalnej przeszłości na Ukrainie, której współczesnego terytorium dotyczy w wielkiej części. Mamy nadzieję, że wzbudzi też zainteresowanie na szerszym forum, w Austrii i innych krajach „sukcesyjnych” dawnej monarchii Habsburgów, a ponadto wśród specjalistów z zakresu historii kartografii i geografii historycznej.

W dalszych planach wydawcy przewidują opracowanie wersji cyfrowej na bazie przygotowanego wcześniej materiału edycji drukowanej, a więc pozyskanego zdigitalizowanego zasobu kartograficznego, ustalonego, opracowanego i przetłumaczonego tekstu źródłowego opisów wojskowych, sporządzonych inwentarzy toponimii i indeksów oraz objaśnień i komentarzy. Ta postępująca w ślad za edycją „papierową” wersja elektroniczna powinna zawierać zgeokodowaną mapę cyfrową, gdzie każdy punkt miałby przypisane współrzędne geograficzne, zaś aktywne powiązania między mapą historyczną, wspótczesną mapą topograficzną, odpowiadającym opisem w części tekstowej i hasłem w wykazie toponimii oraz indeksie, dałyby użytkownikowi narzędzia wysoce efektywnej pracy z udostępnionym materiałem źródłowym ${ }^{38}$.

\footnotetext{
${ }^{38}$ Pierwsze testowe próby kalibracji mapy, które uczynnie przeprowadził B. Szady z Katolickiego Uniwersytetu w Lublinie, wypadły obiecująco.
} 


\section{Literatura}

Atlas historyczny Polski. Mapy szczegótowe XVI wieku. Województwo krakowskie $w$ drugiej potowie XVI wieku, red. H. Rutkowski, Warszawa 2008.

Atlas historyczny Polski. Mapy szczegótowe XVI wieku. Województwo sandomierskie $w$ drugiej potowie XVI wieku, red. W. Pałucki, Warszawa 1993.

Balzer O., O Morskie Oko. Wywód praw polskich przed sadem polubownym $w$ Gradcu, Lwów 1906 (wcześniej w „Przewodniku NaukowoLiterackim", 22-23, 1904-1905).

Bettlack, Anleitung, Situations-Plane zu zeichnen. Zum Gebrauch der Churfl. Sächsischen Ritter-Akademie entworfen und zusammen getragen vom Hauptmann Bettlack, Lehrer der Fortifikation, Dresden 1784.

Bukowski W., Die handschriftliche topographische Karte des Konigreiches Galizien und Lodomerien - die sogenannte Miegkarte - der Jahre 1775 -1783 in den Sammlungen des Kriegsarchivs in Wien sowie das Projekt ibrer Herausgabe, "Jahrbuch des Wissenschaftlichen Zentrums der Polnischen Akademie der Wissenschaften in Wien", 1 (2007-2008), s. 145-156.

Bukowski W., Dybaś B., Janeczek A., Noga Z., Edycja rękopiśmiennej mapy topograficznej Galicji z lat 1775-1783 (tzw. mapy Miega) z Archiwum Wojennego w Wiedniu, „Kwartalnik Historii Kultury Materialnej”, 59 (2011), nr 1, s. 101-105.

Carte de Cabinet de Pays-Bas autrichiens levée à l'initiative du comte de Ferraris. Mémoires historiques, chronologiques et oeconomiques, 12 tomów map, 12 tomów opisów, Bruxelles 1965-1974.

Carte de Ferraris (Carte de Cabinet des PaysBas autrichiens) (dostęp : http://belgica.kbr. be/fr/coll/cp/cpFerraris_fr.html, 9 kwietnia 2913).

Czołowski A., Sprawa sporu granicznego przy Morskim Oku. Wywód historyczno-prawny, Lwów 1894.

Digitaler Atlas der Steiermark (dostęp: http:// www.gis.steiermark.at, 9 kwietnia 2913).
Dörflinger J., Die Landesaufnahmen des österreichischen Generalquartiermeisterstabes 1749 1854, Fachhochschule Karlsruhe. Karlsruher Geowissenschaftliche Schriften. Reihe C: Alte Karten, Bd. 2, Karlsruhe 1989.

Dörflinger J., Die Österreichische Kartographie im 18. und zu Beginn des 19. Jahrhunderts unter besonderer Berücksichtigung der Privatkartographie zwischen 1780 und 1820, Bd. 1: Österreichische Karten des 18. Jahrhunderts, Wien 1994.

Dörflinger J., Vom Aufstieg der Militärkartographie bis zum Wiener Kongress (1684-1815), w: I. Kretschmer, J. Dörflinger, F. Wawrik, Österreichische Kartographie. Von den Anfängen im 15. Jahrhundert bis zum 21. Jahrhundert, Wiener Schriften zur Geographie und Kartographie 15, Wien 2004.

Il Ducato di Venezia nella carta di Anton von Zach, wyd. M. Rossi, vol. I-III, Treviso 2005.

Az elsö katonai felmérés: Erdély és a Temesi Bánság. Die erste militärische Vermessung: Siebenbürgen und das Banat des Temes, DVD, Budapest 2005, 2007.

Az elsö katonai felmérés: Magyar Királyság. Die Josephinische Aufnahme. Die erste militärische Vermessung: Königtum Ungarn, DVD, Budapest 2004, 2006.

De grote atlas van Ferraris: de eerste atlas van België: Kabinetskaart van de Oostenrijkse Nederlanden en het Prinsbisdom Luik, 1777. Le grand atlas de Ferraris: le premier atlas de la Belgique: carte de Cabinet des Pays-Bas autrichiens et de la Principauté de Liège, 1777, wyd. W. Bracke, S. Lammens, Brussel 2009, 2011. Hillbrand E., Die Kartensammlung des Kriegsarchivs Wien, „Mitteilungen des Österreichischen Staatsarchivs”, 28 (1975), s. 183-196. Hillbrand E., Z problematyki badawczej źródtowych zasobów kartograficznych Kriegsarchiv $w$ Wiedniu, „Sprawozdania $\mathrm{z}$ posiedzeń naukowych PAN, Oddział w Krakowie", 30 (1988), 1-2, s. 234-236.

Hofstätter E., Beiträge zur Geschichte der österreichischen Landesaufnahmen, T. 1-2, Wien 1989. 
Hrvatska na tajnim zemljovidima XVIII. i XIX. stoljeća, wyd. M. Valentić [et al.], svazek 1-12, Zagreb 1999-2009.

Instrukcja wydawnicza dla źródet historycznych od XVI do potowy XIX wieku, red. K. Lepszy, Wrocław 1953.

Jabłonowski A., Atlas historyczny Rzeczypospolitej Polskiej wydany z zasitkiem Akademii Umiejętności w Krakowie, [T. 1], Epoka przetomu z wieku XVI-ego na XVII-sty. Dziat II-gi. „Ziemie Ruskie" Rzeczypospolitej, Warszawa-Wiedeń 1889-1904.

Janeczek A., Osadnictwo pogranicza polsko-ruskiego. Województwo betskie od schytku XIV do poczatku XVII w., Wrocław 1991.

Jankó A., An outstandingperson of the 1st military survey: Mihály Lajos Jeney, „Térképtudományi Tanulmányok", 13 (2006), s. 201-207.

Keferstein J. F., Anfangsgründe zu praktisch geometrischen Zeichnungen und Vermessungen, die zur Anfertigung und Abzeichnung der oeconomischen, militärischen und geographischen Charten ... nötig sind, Leipzig 1778.

Klein B., Významné mestá Slovenska na tajných mapách 18. storočia, Bratislava 2003.

Konias A., Kartografia topograficzna Ślaska Cieszyńskiego i zaboru austriackiego od II potowy XVIII w. do poczatku XX w., Katowice 2000.

Konopczyński W., Pierwszy rozbiór Polski, Kraków 2010.

Landerer F., Gründliche Anleitung SituationsPlane zu zeichnen. Zum Gebrauche der $k$. $k$. Ingenieur-Akademie, wie auch jener, die sich den Mappirungs-Geschäften widmen, Wien 1782 oraz Wien 1783 (kolejne edycje 1796, 1805, 1812).

Liesganig J., Regna Galiciae et Lodomeriae Josephi II et M[ariae] Theresiae aug[ustorum] iussu methodo astronomico-trigonometrica, nec non Bukovina geometrice dimensa, 1:288 000, [Vindobonae 1790].

Mackiewicz J. von, Anweisung Situationsplane zu zeichnen und zu illuminiren, Prag 1798 (kolejne wyd. Prag 1806, 1819, 1821).

Mapa Rzeczypospolitej Polskiej, 1:1 000 000, Warszawa 1934.
Müller G., Empfehlungen zur Edition frühneuzeitlicher Texte, „Archiv für Reformationsgeschichte", 72 (1981), s. 299-315.

Nöbauer I., „Höchst vorläufige Bemerckungen zu dero Sprachkunst dero Josephinischen Landesaufnahme Galizien und Lodomerien" - Zu den sprachlichen Besonderheiten der so genannten Miegkarte, „Jahrbuch des Wissenschaftlichen Zentrums der Polnischen Akademie der Wissenschaften in Wien", 3 (2012), s. 43-58.

Paldus J., Die Einverleibung Galiziens und der Bukowina in die österreichische Monarchie im Jahre 1772, „Mitteilungen der k. k. Geographischen Gesellschaft in Wien“, 59 (1916), s. 417-455.

Paldus J., Die militärischen Aufnahmen im Bereiche der Habsburgischen Länder aus der Zeit Kaiser Josephs II., Akademie der Wissenschaften in Wien, Philosophisch-historische Klasse, Denkschriften, Bd. 63, 2. Abhandlung, Wien 1919.

Petryšyn H. P., Karta F. fon Miga (1779-1782 rr.) jak džerelo do mistoznavstva Halyčyny, L'viv 2006.

Prezentace starých mapových děl z území Čech, Moravy a Slezska (dostęp: http://oldmaps. geolab.cz, 9 kwietnia 2913).

Regele O., Beiträge zur Geschichte der staatlichen Landesaufnahme und Kartographie in Österreich bis zum Jahre 1918, Wien 1955.

Rill R., Die Anfänge der Militärkartographie in den habsburgischen Erblanden: Die Josephinische Landesaufnahme von Böhmen und Mähren nach hofkriegsrätlichen Quellen, „,Mitteilungen des Österreichischen Staatsarchivs", 49 (2001), s. 183-202.

Roskiewicz J., Kartographie, w: Weltausstellung 1873 in Wien. Beiträge zur Geschichte der Gewerbe und Erfindungen Oesterreichs von der Mitte des XVIII. Jahrhunderts bis zur Gegenwart, hrsg. von der General-direction, redigirt von Prof. Dr. Wilhelm Franz Exner, 2. Reihe, Wien 1873.

Roskiewicz J., Die Kartographie in Österreich vom Jahre 1750 bis zum Jahre 1873, II. vermehrte Auflage, Wien 1875.

Rossi M., L'officina della Kriegskarte. Anton von Zach e le cartografie degli stati veneti, 1796 1805, Treviso 2007. 
Sawicki L., Obristen Anton Freiherr Mayer von Heldensfeld topographische Aufnahme Westgaliziens in den Jahren 1801-1804. Putkownika Antoniego barona Mayera von Heldensfeld zdjecia topograficzne w Polsce w latach 1801-1804, Prace Instytutu Geograficznego Uniwersytetu Jagiellońskiego, z. 10, Kraków 1928.

Sawicki L., Spis map Archiwum Wojennego $w$ Wiedniu odnoszacych sie do ziem polskich, Warszawa 1920.

Slovenija na vojaškem zemljevidu 1763-1787. Josephinische Landesaufnahme 1763-1787 für das Gebiet der Republik Slowenien, wyd. V. Rajšp [et al.], zvezek 1-7, Ljubljana 1995-2001.

Tielke J. G., Unterricht für die Officiers, die sich zu Feld-Ingenieurs bilden, oder doch den Feldzügen mit Nutzen beywohnen wollen, durch Beyspiele aus dem letzten Kriege erläutert, und mit nöthigen Plans versehen, Dresden 1769 (wyd. 2, Dresden 1774; wyd. 3, Dresden
1779; wyd. 4, Wien 1785; kolejne edycje 1795, 1818).

Tomeček O., Na margo obsahu exemplárov máp 1. vojenského mapovania, w: Historické mapy. Zbornik referátov z vedeckej konferencie, Bratislava 2009, s. 146-149.

Topographische Karte von Ostgalizien und Lodomerien in 14. Sectionen nach den neuesten Aufnahmen, hrsg. von dem Galizischen Strassenbaudirektor Gross, ok. 1:144 000, Wien [ok. 1815].

Voch L., Die Kunst Situationsplane mit Hülfe einer besonders dazu verfertigten Schreibtafel und auf andere verschiedene Arten aufzunehmen und zu zeichnen, Augsburg 1774 (wyd. 2, Augsburg 1781).

Zaffauk J., Signaturen in- und ausländischer Plan- und Kartenwerke, nebst Angabe der in Karten und Plänen am häufigsten vorkommenden Worte und Wort-Abkürzungen in 12 Sprachen, 2., vermehrte Auflage, Wien 1889.

\section{Josephine map of Galicia (1779-1783) on the eve of the edition. The subject and assumptions of the publishing plan}

\section{Summary}

As a result of the first partition of Poland (1772) Austria occupied two big districts, namely the southern part of Lesser Poland and Red Ruthenia. The newly incorporated crownland, called the Kingdom of Galicia and Lodomeria, was mapped within Josephine survey already a few years after annexation. The name of Josephine survey (or the first military survey) refers to a series of topographic maps made in the years 1763-1787, which covered the successive territories under the rule of the Habsburg dynasty (fig. 1). In the case of the map of Galicia, the same principles were adopted as those for the whole Josephine survey. The map was prepared in a 1:28 800 scale model on the basis of field measurements but also using the ,à la vue” method, with a plane table and other instruments.

The Josephine map of Galicia, initially made secret due to its military importance, was never published and remains in a manuscript till now, kept in the War Archives in Vienna. It consists of 413 sheets in the format of $24 \times 16$ inches $(63.2 \times 42.1 \mathrm{~cm})$ and additional sheets of varying formats. Its total surface is about $115 \mathrm{~m}^{2}$. Two sets of hand-written copies (fig. 3) have been preserved besides the original (an example in fig. 2). The map is accompanied by six bulky volumes including descriptions of the mapped area (one of the sheets is presented in fig. 4).

Due to the value of the map as a source and its usefulness for historical as well as geographical studies and studies conducted within other disciplines, postulates were put forward for this relic to be made available in print. Those intentions were made specific in 2008, when work was begun on preparing a full edition of Galicia's map which would include both the cartographic material and the text (topographic descriptions). Four editorial groups 
are concerned with this and they are headed by Waldemar Bukowski (Institute of History of the Polish Academy of Sciences, Cracow), Zdzisław Noga (Institute of History, Pedagogical University of Cracow), Andrzej Janeczek (Institute of Archeology and Ethnology of the Polish Academy of Sciences, Warsaw) and Zdzisław Budzyński (Institute of History of the University of Rzeszów).

The material was divided into fifteen volumes of a similar size (fig. 5). Each volume will be composed of two volumes. One will include facsimiles of the sheets of the map, from 20 to 46. The other volume will contain texts of descriptions in German with a parallel translation into Polish, commentaries to the descriptions, an inventory of names included in the map, a joint index of maps and descriptions and, finally, explanations to the symbols and the map captions. Further plans provide for a digital version on the basis of the prepared material of the printed version.

Stowa kluczowe: historia kartografii, mapy topograficzne, dawne mapy Galicji.

Keywords: history of cartography, topographic maps, old maps of Galicia.

dr hab. Andrzej Janeczek - profesor w Instytucie Archeologii i Etnologii PAN, kierownik Ośrodka Historii Kultury Materialnej Średniowiecza i Czasów Nowożytnych; prowadzi projekt badawczy: „Rękopiśmienna mapa topograficzna Królestwa Galicji i Lodomerii (tzw. mapa Miega) z lat 1775-1783 - odczytanie i ttumaczenie opisów do arkuszy map 202-312, przygotowanie krytycznej edycji jednego tomu", N N108 187440, (e-mail: an.janeczek@gmail.com).

mgr Waldemar Bukowski - pracownik Instytutu Historiii PAN, Oddział w Krakowie; kierownik Pracowni Słownika Historyczno-Geograficznego Małopolski w Średniowieczu; prowadzi projekt badawczy „Rękopiśmienna mapa topograficzna Królestwa Galicji i Lodomerii (tzw. mapa Miega) z lat 1775-1783 - przygotowanie do edycji opisów do map 94-200; przygotowanie krytycznej edycji jednego tomu", N N108 032835, (e-mail: bukowski@ih.pan.krakow.pl). 